\title{
DOKLADY O RYBNIČNOM HOSPODÁRSTVE NA ČERVENOKAMENSKOM PANSTVE
}

\section{MARTIN NEUMANN}

\begin{abstract}
Abstrakt: Tradicia rybnikárstva ako jednej z foriem rybárstva a rybolovu má na územi Slovenska dlhú tradíciu. Jeho obdobie rozkvetu v tunajšom prostredi však predstavuje predovšetkým 16. storočie. V tomto obdobi vznikla sústava rybnikov aj na červenokamenskom panstve, za čo vd'ači predovšetkým hospodárskym aktivitám jeho nových majitelov - Fuggerovcov. Písomné pramene týkajúce sa miestneho rybnikárstva sú vel'mi skúpe. Konfrontáciou s rôznymi druhmi kartografických zobrazení a priamou identifikáciou pozostatkov rybničných hrádzí v krajine sa autor snaži priniest’ nové poznatky k tejto doposial málo poznanej kapitole histórie červenokamenského panstva v novoveku.
\end{abstract}

Kl'účové slová: rybnikárstvo - Červený Kameñ - stredovek - novovek.

\section{Evidence of fishpond economy on the Červený Kameň estate}

Abstract: The tradition of fishpond economy as one of the forms of the fishing industry has a long tradition in Slovakia. Its heyday is predominantly associated with the 16th century. This period gave rise to a system of fishponds on the Červený Kameň estate, chiefly credited to the economic activities of the estate's new owners, the Fugger family. Written sources concerning the local fishpond economy are scarce. Through comparison with different kinds of cartographic images and direct identification of the remains of the retaining walls of fishponds in the landscape, the author brings new information about this little-investigated chapter in the history of the Červený Kameñ estate in the modern age.

Key words: fishpond industry - Červený Kamě̌ - Middle Ages - modern age.

\section{Úvod}

Rybnikárstvo predstavuje jednu z vývojových foriem rybárstva. Kým rybolov a jeho doklady v živej či mŕtvej l’udskej kultúre sú už dlhodobo predmetom záujmu odbornej verejnosti, stav poznania vývoja rybnikárstva je minimálne v slovenskej vedeckej obci na nízkej úrovni (porovnaj Zacharová 2008, 33-36). Táto skutočnost' je o to viac zarážajúcejšia, že doklady po rybnikárstve možno ešte dnes nájst' v otvorenej krajine. Platí to i pre územie červenokamenského panstva, ktoré leží na juhozápadnom Slovensku (obr. 1). Na jeho príklade sa pokúsime demonštrovat' postup pri identifikácii reliktov po rybnikárstve v krajine. Už na prvý pohl'ad je zrejmé, že takýto postup sa nezaobíde bez podrobného štúdia nielen historických, no i relevantných kartografických či archeologických prameňov. Len tie totiž dokážu presne lokalizovat' jednotlivé rybníky, ako na to bude poukázané d’alej v texte. Predtým, než pristúpime k rekonštrukcii rybničnej siete na červenokamenskom panstve, stručne predstavíme práce zaoberajúce sa primárne či aspoň okrajovo problematikou rybnikárstva na území dnešného Slovenska.

\section{Rybnikárstvo ako predmet štúdia}

Možno konštatovat', že o vývoji rybnikárstva na Slovensku sa dodnes vie vel'mi málo (Jeršová 1957, 157-171; Neumann 2016, 182-187). Ešte i dnes na Slovensku absentuje práca, ktorá by naṕlńala kvalitu i obsah podobných prác v zahraničí (napr. Hurt 1960). O niečo väčšiu pozornost' prit’ahovala téma rybárstva a rybolovu, ku ktorej vzniklo už viacero prác (Hermann 1887; Wenzel 1887; Martinka 1931; Mjartan 1984). Naposledy sa stredovekým rybárstvom najobšírnejšie zaoberal M. Kučera (Kučera 1974). Hoci táto práca zostala v mnohých ohl'adoch podnes neprekonaná, o rybníkoch sa zmieňovala len vel'mi okrajovo. Ovel’a prínosnejšími boli v tomto ohlade štúdie M. Jeršovej, Š. Janšáka a najmä M. Skladaného, ktorý sa sústredil na aktivity Fuggerovcov na červenokamenskom panstve v 16. storočí, ku ktorým patrila aj čulá rybnikárska činnost' (Jeršová 1957; Janšák 1961; Skladaný 1965). Tej sa okrajovo dotkol aj J. Žudel 
pri vyhodnocovaní vplyvov ekonomickej činnosti fuggerovských aktivít na životné prostredie (Žudel 1974, 163-174). Ak pominieme práce dotýkajúce sa rybnikárstva len okrajovo, najintenzívnejšie sa v súčasnosti problematike identifikácie zaniknutých rybníkov na Slovensku venuje P. Chrastina (Rábik-Labanc-Tibenský 2013, 23; Chrastina 2005, 43-55; Chrastina 2009; Chrastina 2010). K nemu možno priradit’ aj P. Maliniaka, ktorý sa pokúsil zrekonštruovat' krajinu Zvolenskej kotliny v stredoveku (Maliniak 2009). Omnoho priaznivejšiu situáciu z pohl’adu záujmu o rybníky je možné sledovat' v Čechách a na Morave, kde sa téma rybnikárstva už dlhodobo teší väčšiemu záujmu. Svedčia o tom najmä staršie práce A. Míku, R. Hurta a J. Andresku (Míka 1955; Hurt 1960; Andreska 1997). Z mladšej generácie autorov nesmieme opomenút' R. Šimůnka, B. Veverku a M. Čechurovú, R. Pavelkovú Chmelovú, J. Frajera, P. Pavku, M. Dzurákovú či P. Adámka (Frajer-Pavelková Chmelová 2009; Pavelková Chmelová a kol. 2012; Veverka-Čechurová 2012; Šimůnek 2015).

Množstvo písomných prameňov vzt’ahujúcich sa k rybničnému hospodárstvu na červenokamenskom panstve je pomerne skromné. Predkladaná štúdia si kladie za ciel' nielen zosumarizovat' poznatky o rybničnej sústave na červenokamenskom panstve v období novoveku, no i pokúsit' sa priniest' na základe kartografických prameňov a terénneho prieskumu nové informácie ohl'adom ich polohy v krajine či približnej dobe ich zániku. Ako základné pramene pre získanie týchto informácií slúžia v prostredí bývalého Uhorského královstva predovšetkým vojenské mapovania, katastrálne mapy, prípadne aj staršie mapové diela (pre územie Slovenska najmä mapy jednotlivých žúp z diela Mateja Bela Notitia Hungariae Novae Historico-Geographica). Výnimočnú výpovednú hodnotu poskytuje konfrontácia mapových diel v kombinácii s písomnými prameňmi a priamou identifikáciou pozostatkov rybníkov v súčasnej krajine.

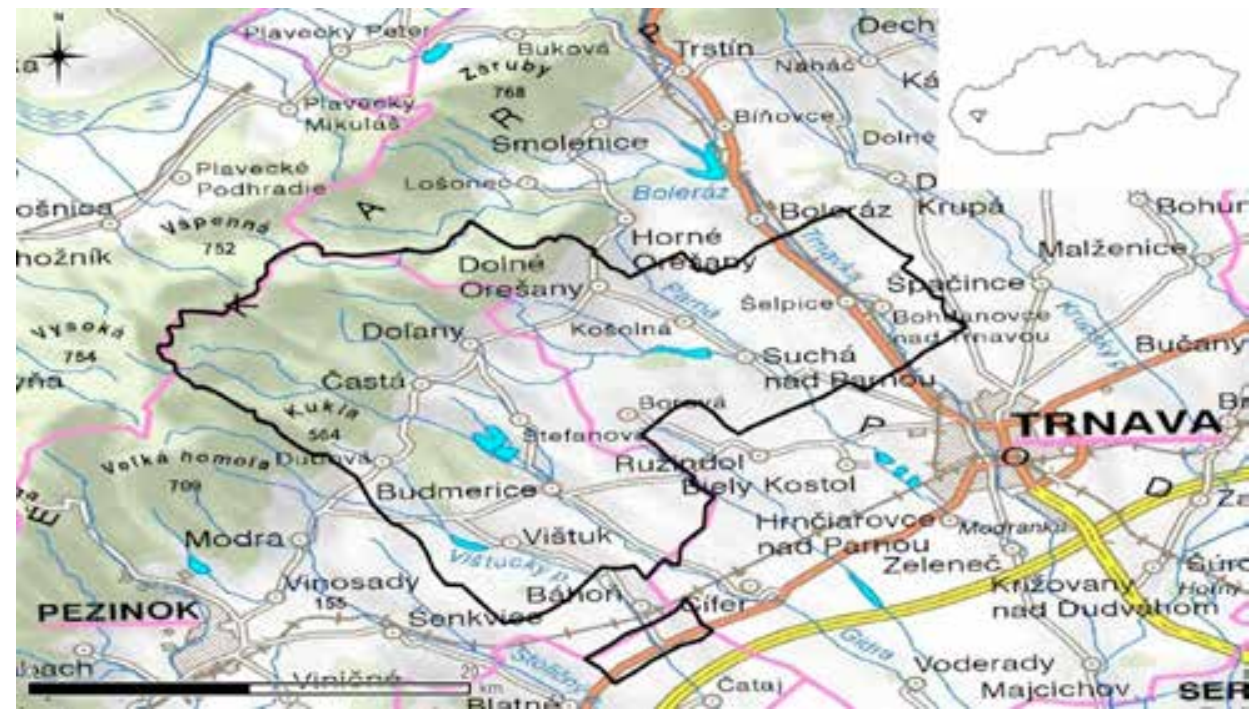

Obr. 1. Lokalizovanie červenokamenského panstva na juhozápadnom Slovensku.

Abb. 1. Lokalisierung der Herrschaft Červený Kameň in der Südwestslowakei.

\section{Historické pozadie vzniku rybníkov na červenokamenskom panstve}

Vznik rybníkov na červenokamenskom panstve úzko súvisí s jeho vlastníckymi pomermi. Podl’a kronikára Přibíka Pulkavy z Radenína založila hrad Červený Kameň (Rotenstein) dcéra uhorského krála Bela III. a neskoršia česká královná Konštancia (KRONIKA ČESKÁ, 356). Hoci v kronikárskom zázname nebol uvedený presný rok založenia hradu, možno predpokladat', 
že sa tak stalo niekedy v prvej tretine 13. storočia. V roku 1296 hrad odkúpil Matúš Č́a Trenčiansky, no po jeho smrti v roku 1321 pripadol uhorskému král’ovi Karolovi I. Róbertovi (Plaček 2007, 94). Jeho syn L’udovít I. Vel'ký hrad spolu s celým panstvom daroval v roku 1364 príslušníkom rakúskeho rodu Wolfurtovcov (Tibenský 2011, 67). Tí ho vlastnili až do roku 1442. Manželka posledného vlastníka hradu z rodu Wolfurtovcov, a teda jeho dedička - Jitka Opavská, sa po manželovej smrti vydala za Juraja, grófa zo Svätého Jura a Pezinka, a hrad s celým panstvom venovala svojmu manželovi (Tibenský 2011,75). Nárok na panstvo však vzniesli aj d’alší príbuzní Wolfurtovcov - Héderváriovci. Spory o vlastníctvo hradu trvali až do konca 15. storočia (Tibenský 2011, 75-82). Vít’azne z nich vyšli svätojurskí a pezinskí grófi Peter a Tomáš. V roku 1511 Peter vo svojom testamente zálohoval červenokamenské panstvo tešínskej vojvodkyni Hedvige a jej synom Jánovi a Jurajovi Zápol'ským (Tibenský 2011, 88; Kucharská 2014, 68). Po Petrovej smrti v roku 1517 došlo k novým sporom medzi rodom Zápol'ských a grófmi zo Svätého Jura a Pezinka. Do nich však vstúpil král' Luudovít II. Jagellonský a celé panstvo zhabal. Dňa 15. augusta 1522 ho král' venoval svojej manželke Márii (MOL, DL). Tá ho však už o rok neskôr dala do užívania král'ovskému komorskému grófovi Alexejovi Turzovi (Tibenský 2011, 93). V roku 1535 odkúpil od neho panstvo Anton Fugger za 105401 uhorských zlatých (Žudel 1991, 18; Kalus 1999, 232). Práve aktivity tohto bankárskeho a podnikatel'ského rodu sa výrazne podpísali pod zmeny $\mathrm{v}$ hospodárení na červenokamenskom panstve.

Rýchle striedanie majitel’ov v období stredoveku panstvu príliš neprospievalo. K jeho rozvoju na počiatku 16. storočia istotne neprispievali mocenské konflikty v krajine či z juhu sa blížiace nebezpečenstvo vo forme osmanských vojsk (Žudel 1970, 20). V roku 1530, teda len pár rokov pred zakúpením panstva Fuggerovcami, vyplienili osmanské vojská smederevského bega Mehmeda po neúspešnom obliehaní Viedne široké okolie Trnavy (Dangl 2005, 95; Lopatková 2010, 68; Roháč 2010, 139). Týmto spôsobom utrpeli značné škody obce Šelpice a Bohdanovce, patriace pod správu hradu Červený Kameň (Benková 2013, 340). Nebezpečenstvo však predstavovali aj rabujúce krest’anské žoldnierske vojská. Známy je prípad v bezprostrednom susedstve červenokamenského panstva ležiacej obce Ružindol, ktorá bola v roku 1532 vyplienená žoldniermi španielskeho král'a Karola V. (Mrva 2014, 44). V dôsledku častých konfliktov mnohé obce na panstve spustli. Z urbára červenokamenského panstva z roku 1543 vyplýva, že krátko po jeho kúpe Fuggerovcami bolo viacero dedín úplne či čiastočne opustených. Medzi ne patrili Šelpice, Nemečín, Klčovany a Fančal (Marsina 1959, 97, 105, 142, 157).

Vyludnené a hospodársky upadnuté panstvo sa Fuggerovci snažili hospodársky pozdvihnút'. V prvom rade bolo nutné priviest' do vyl'udnených dedín nové obyvatel'stvo. V dôsledku toho sem Fuggerovci začali pozývat' nových obyvatel’ov, predovšetkým z územia dnešného Chorvátska. Z písomných prameňov je známe, že sa Chorváti usadili v Častej, Dol’anoch, Šelpiciach, Bohdanovciach, Nemečíne, Zvončíne, Dubovej, Suchej nad Parnou, Košolnej, Dlhej, Jablonci, Kaplnej, Budmericiach a Vištuku (Benková 2013, 339-343). Anton Fugger však hodlal pozdvihnút' hospodársku úroveň panstva aj inými aktivitami, v tomto prípade budovaním rybníkov. S vel'kou pravdepodobnostou nadviazal na staršiu rybnikársku tradíciu, ktorá sa na panstve rozvíjala už dlhší čas. Je totiž možné, že na panstve existovali akési rybníky už pred rokom 1535, ked' prišlo k zakúpeniu panstva Fuggerovcami. Na ich existenciu by mohla poukazovat' listina uhorského krála Ludovíta II. z 15. augusta 1522, ktorou král' okrem iného daroval svojej manželke Márii hrad Červený Kameň so všetkými „,terris scilicet arabilibus cultis et incultis, agris, pratis, pascuis, campis, foenetis, silvis, nemoribus, montibus, vallibus, vineis, vinearumque promontoriis, aquis, fluviis, piscinis, piscaturis aquarumque..." (MOL, DL). Ďalšiu indíciu poukazujúcu na existenciu rybníkov na červenokamenskom panstve už pred rokom 1535 možno nájst' v diele českého humanistu a budúceho olomouckého biskupa Jána Dubravia. Ako blízky priatel' Antona Fuggera bol pozvaný na jeho novonadobudnuté panstvo v Uhorsku za účelom jeho zvel’adenia. Ján Dubravius skutočne podnikol cestu do Uhorska na hrad Červený Kameň, kde strávil 4 dni. Počas nich radil správcovi hradu, akým spôsobom najlepšie pozdvihnút' upadajúce panstvo. Ako najviac zanedbaný zhodnotil práve stav miestnych rybníkov. Potvrdzujú to 
aj slová v úvode jeho útleho diela Libellus de piscinis et piscium, kde konštatoval: „zvolil jsem si hlavně péči o rybniky, protože jsem viděl, že při nich je nápravy nejvice třeba" (Dubravius 1953, 25). Je teda možné predpokladat', že rybníky na červenokamenskom panstve existovali už pred rokom 1535 .

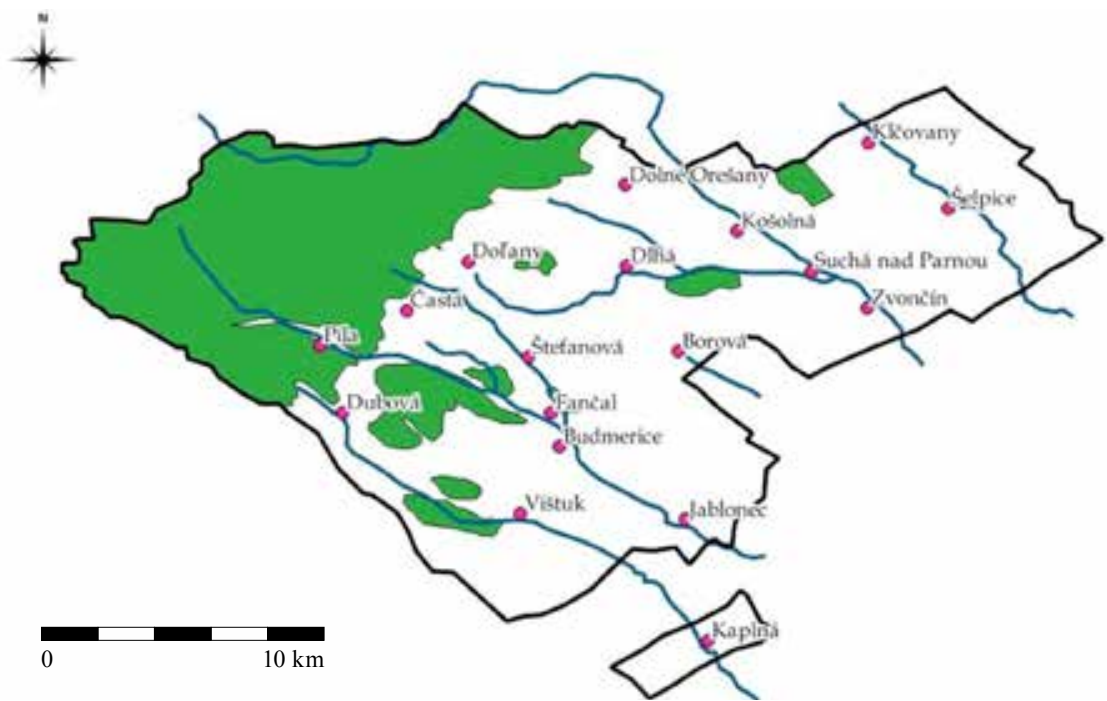

Obr. 2. Mapa červenokamenského panstva s riečnou siet’ou a k nemu prislúchajúcich sídel v 16. storočí (kvôli prehl’adnosti je pridaná aj zaniknutá dedina Fančal, ako i dedina Štefanová, ktorá bola založená až v roku 1588). Tmavšie plochy reprezentujú lesný porast.

Abb. 2. Karte der Herrschaft Červený Kameň mit Flussnetz und den zu ihr gehörenden Orten (der Übersichtlichkeit halber wurde auch die Dorfwüstung Fančal sowie das erst 1588 gegründete Dorf Štefanová hinzugefügt). Die dunkleren Flächen repräsentieren Waldflächen.

\section{Červenokamenské panstvo}

Červenokamenské panstvo leží na východných svahoch pohoria Malých Karpát a rozprestiera sa na západnom okraji Trnavskej pahorkatiny (obr. 2). Na počiatku 16. storočia prináležali panstvu viaceré dediny, ktoré zachytil urbár z roku 1543. Patrili k nim Častá, Dolany, Dolné Orešany, Šelpice, Bohdanovce, Nemečín, Zvončín, Suchá nad Parnou, Košolná, Dlhá, Jablonec, Kaplná, Budmerice, Vištuk, Dubová a Klčovany (Marsina 1959, 70-142). Pôvodne sa na panstve v 15. storočí nachádzala aj dedina Fančal, ktorá však bola v čase spísania urbáru pustá (Marsina 1959, 157). Severozápadnú prirodzenú hranicu panstva tvorili hrebene Malých Karpát. V nich pramenili viaceré vodné toky, ktoré pretínali územie panstva zo severozápadu smerom na juhovýchod. Vd’aka zvlnenému terénu trnavskej pahorkatiny boli údolia viacerých vodných tokov využité na konci stredoveku, no najmä na začiatku novoveku na výstavbu rybníkov. Ako najpríhodnejšie sa v tomto smere ukázali potoky Parná a Gidra s ich prítokmi a Vištucký potok. Všetky toky poslúžili na výstavbu 11 väčších či menších rybníkov, čo dokladá aj zápis $\mathrm{v}$ urbári z roku 1543 (Marsina 1959, 157). Výslovne sa spomínajú tieto rybníky: Geselsdorff teücht, Oberschanawer teücht, Unnterschonawer teucht, Newschönawer teuch, Unnder Pomeritzer Teuch, Fanntzeldorffer Teüch, Ober Langendorffer Streicher, Unnder Langendorffer Streicher, Ober Wischtuecher teüch, Unter Wischtüecher teücht a Schneggen teucht.

Pomenovania väčšiny rybníkov boli odvodené od názvu obce, v chotári ktorej sa nachádzali. Názvy Geselsdorff, Pomeritz, Langendorff či Wischtuech sa vzt’ahujú na dnešné obce 
Košolná, Budmerice, Dlhá a Vištuk. Pomenovanie Schanaw/Schonaw sa viaže na dnes už zaniknutú dedinu, ktorá ležala v priestore medzi dnešnými Budmericami, Štefanovou a Častou. Názov zaniknutej dediny (Horný) Fančal - Fanntzeldorff, ktorý sa dodnes zachoval v pomenovaní polohy na l’avom brehu Štefanovského potoka severne od budmerického Horného dvora, upresňuje polohu rybníka Fanntzeldorffer Teüch. Ako vidno, samotné mená rybníkov poskytujú prvý záchytný bod pre lokalizáciu rybníkov, a to s presnost’ou na kataster obce (obr. 3).

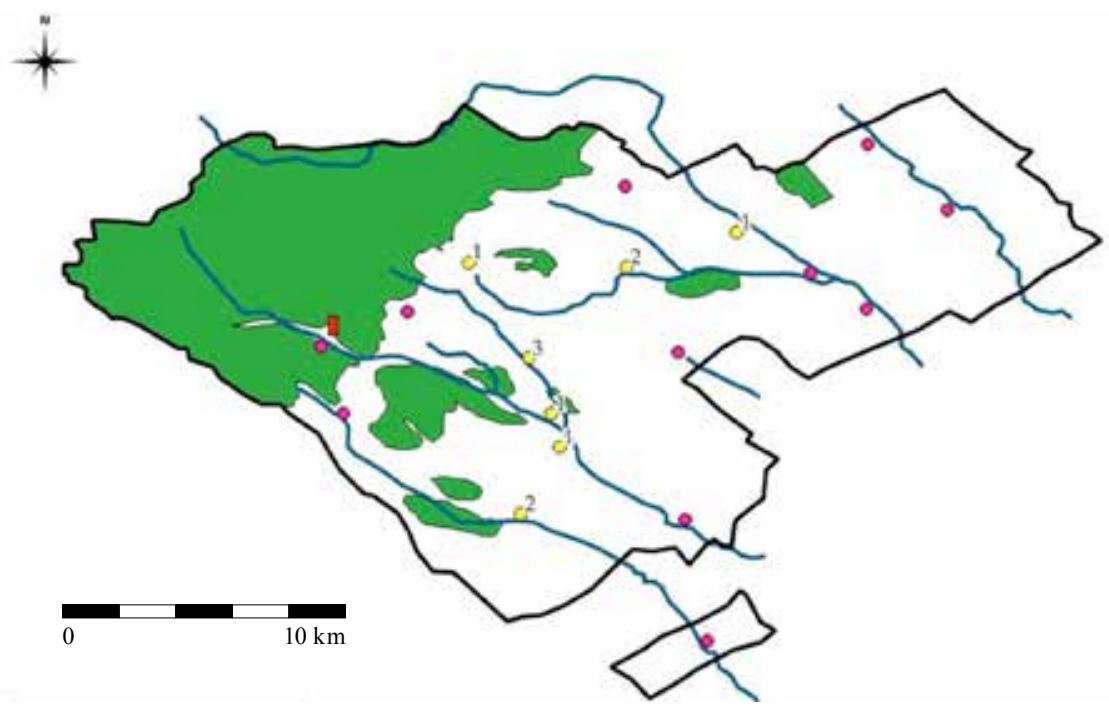

Obr. 3. Mapa červenokamenského panstva s riečnou siet'ou. Tmavý obdížnik reprezentuje hrad Červený Kameň, jednotlivé body sídla na panstve. Čísla pri bodoch naznačujú počet rybníkov, ktoré v katastri konkrétneho sídla zachytil urbár z roku 1543. Kvôli nie presne známej polohe zaniknutej dediny Schönau boli tri schönauské rybníky priradené k obci Štefanová (porovnaj s obrázkom 2).

Abb. 3. Karte der Herrschaft Červený Kameň mit Flussnetz. Das dunkle Rechteck repräsentiert die Burg Červený Kameň (Bibersburg), die einzelnen Punkte die Orte der Herrschaft. Die Zahlen bei den Punkten geben die Anzahl der Teiche an, die im Kataster des jeweiligen Ortes im Urbar von 1543 erfasst sind. Wegen der nicht genau bekannten Lage der Dorfwüstung Schönau wurden die drei Schönauer Teiche der Gemeinde Štefanová zugeordnet (vgl. mit Abb. 2).

\section{Identifikácia polohy rybníkov na panstve}

Nepostrádatel'nou pomôckou pre identifikáciu rybníkov na území červenokamenského panstva sú mapové podklady z rôznych období. Jedno z prvých mapových diel, ktoré poskytuje pomerne presný obraz skúmaného územia, predstavuje Mappa comitatus Posoniensis accuratione astronomico-geometrica concinnata. Ide o mapu Prešporskej stolice, zhotovenú v roku 1735, ktorá je súčastou série máp uhorských stolíc. Za zhotovením týchto máp stál uhorský král' Karol III., ktorý poveril rektora bratislavského lýcea Mateja Bela zostavením monografického diela o Uhorsku. Ten sa obrátil na Samuela Mikovíniho, uhorského kartografa, ktorý sa aj ujal zhotovenia stoličných máp (Prikryl 1977, 134). V dôsledku kombinácie použitých kartografických metód a mierky 1 : 140000 mohla táto mapa zachytit' krajinné detaily, medzi nimi i rybníky. To však už nemožno tvrdit' o rybničných násypoch, ktoré tu neboli zobrazené. Prípadné zaniknuté rybníky preto na tejto mape nemožno nájst'.

Ovel'a viac informácií je možné vyčítat' z máp 1. vojenského mapovania, a to vd’aka presnejšiemu a detailnejšiemu zachyteniu krajiny za účelom zlepšenia vedenia vojenských akcií. Po skončení rakúsko-pruskej vojny v roku 1763 sa na nariadenie cisárovnej Márie Terézie začalo s podrobným mapovaním všetkých krajín monarchie (Prikryl 1977, 207). Ked’že toto mapovanie 


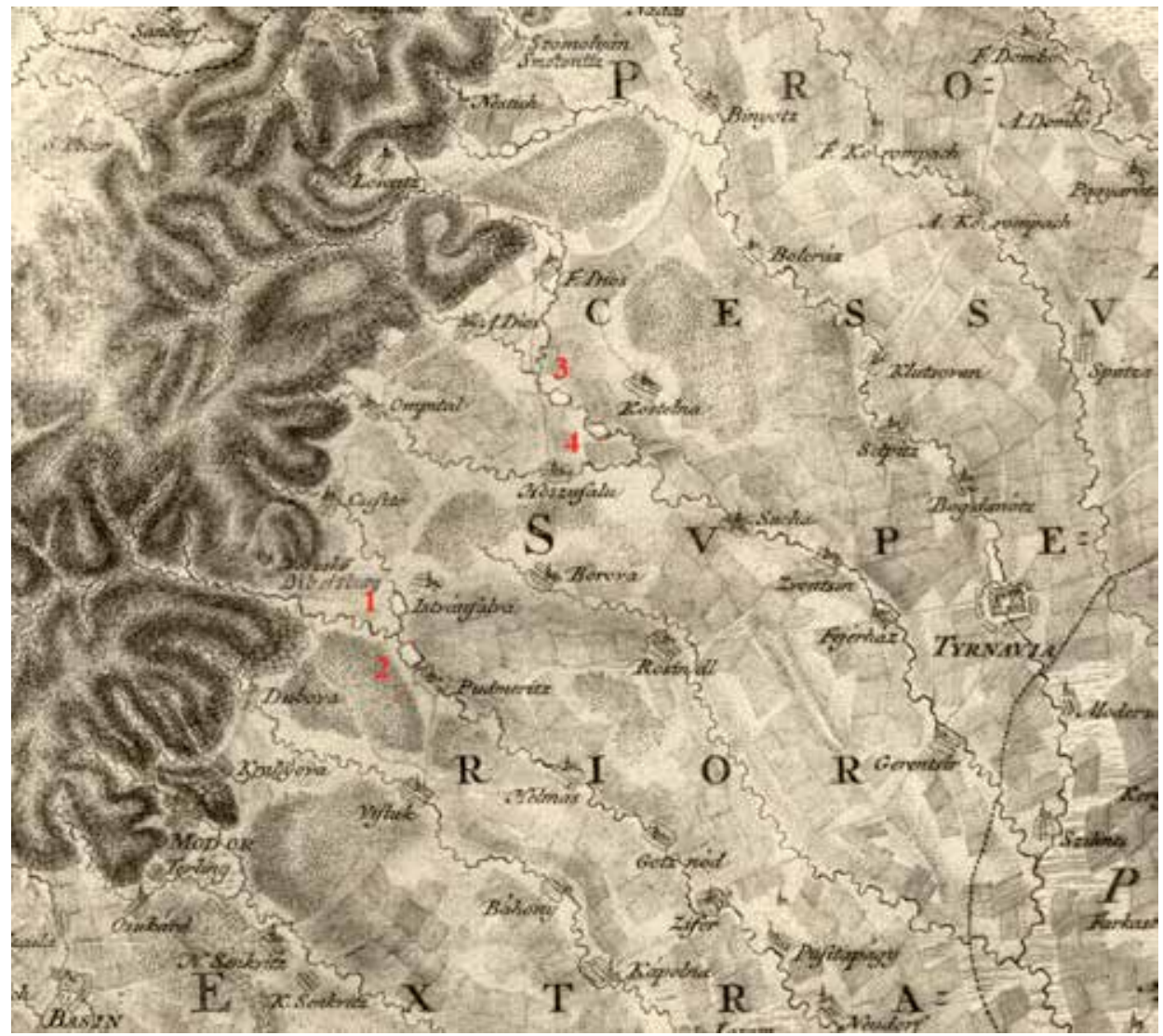

Obr. 4. Mappa Comitatus Posoniensis Accuratione Astronomico-Geometrica concinnata opera z roku 1735.1 - Horný/Dolný schönauský rybník alebo doposial' neznámy rybník; 2 - Nový schönauský rybník; 3 - Horný rybník v Dlhej; 4 - Dolný rybník v Dlhej.

Abb. 4. Mappa Comitatus Posoniensis Accuratione Astronomico-Geometrica concinnata opera aus dem Jahr 1735. 1 - Oberer/Unterer Schönauer Teich oder bisher unbekannter Teich; 2 - Neuer Schönauer Teich; 3 - Oberer Langendorfer Teich; 4 - Unterer Langendorfer Teich.

bolo zhotovované primárne pre vojenské účely, dôraz sa kládol na zachytenie všetkých dôležitých objektov v krajine. Boli to predovšetkým stavby, komunikácie a vodná siet' spoločne s mostmi, brodmi, prievozmi, kanálmi, studňami, prameňmi, rybníkmi a močiarmi. Zachytená mala byt' i morfológia terénu so všetkými vyvýšeninami či priehlbinami (Prikryl 1977, 209). S mapovaním Uhorska sa začalo v roku 1769. Na území dnešného Slovenska sa začalo s prácami na mapovaní jeho severných stolíc susediacich s Pol’skom. S mapovaním západného Slovenska sa pokračovalo až od roku 1782 pod vedením plukovníka Andreasa von Neua. Práce boli ukončené o dva roky neskôr. Jednotlivé mapové listy boli vyhotovené v mierke 1:28 800 (Prikryl 1977, 212; Jankó 2013, 8).

Nedostatky v 1 . vojenskom mapovaní si vyžiadali realizáciu d’alšieho vojenského mapovania. Takzvané 2. vojenské mapovanie prebehlo v Uhorsku v dvoch časových intervaloch (18191829 a 1839-1869). Samotné územie Slovenska bolo mapované v dvoch etapách. Severné a čast' východného Slovenska boli mapované v prvom období, zvyšok Slovenska v druhom období (Prikryl 1977, 301). Oblast' medzi tokom rieky Moravy a Sencom nebola týmto mapovaním spracovaná, čo čiastočne zasiahlo aj čast' červenokamenského panstva. Tento úsek však bol 
doplnený neskôr. Použitá mierka zodpovedala mierke z 1. vojenského mapovania (Jankó-Porubská 2013, 71).

Výhodou oboch vojenských mapovaní je zachytenie najmenších krajinných podrobností, ktoré mohli byt' počas vojenských konfliktov strategicky využitel'né. Vd’aka tomu sa na mapy dostali aj výraznejšie terénne nerovnosti či vyvýšeniny, ktoré mohli eventuálne poskytnút' záchytný bod pre útočiace, prípadne brániace vojenské jednotky. Medzi nimi možno nájst' i stopy po bývalých rybníkoch, ktoré sú na týchto mapách zachytené vo forme reliktov rybničných násypov - hrádzí. Ich znázornenie v mapových podkladoch ponúka možnost' presnejšie lokalizovat' dnes už zaniknuté rybníky a konfrontovat' ich so súčasným stavom krajiny. Porovnávanie viacerých mapových diel medzi sebou navyše ponúka možnost' zúžit' interval, kedy mohli byt' rybníky definitívne vypustené a ponechané svojmu osudu. V nasledujúcom texte sa preto na základe takéhoto porovnávania pokúsime identifikovat' prítomnost' rybníkov, resp. ich reliktov v krajine, a stotožnit' ich s historicky známymi rybníkmi. Budeme pri tom postupovat' po jednotlivých vodných tokoch, na ktorých boli rybníky vybudované. Tomu však bude predchádzat' stručný historický úvod, ktorý pomôže objasnit' nielen dížku používania daného rybníka, no v niektorých prípadoch i jeho polohu.

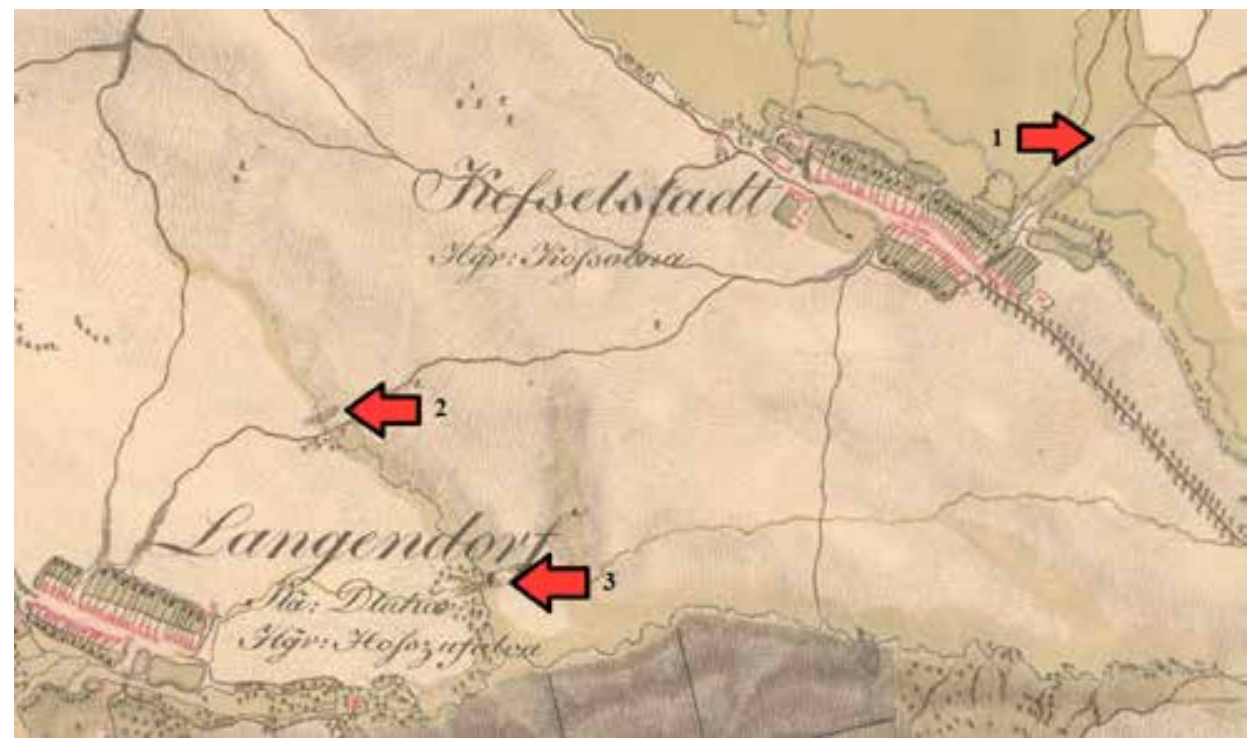

Obr. 5. Dvojica rybničných hrádzí severovýchodne od obce Dlhá na bezmennom prítoku Podhájskeho potoka a zvyšok rybničnej hrádze v susedstve obce Košolná na 2. vojenskom mapovaní. Š́pkami sú označené zvyšky rybničných hrádzí. 1 - rybník v Košolnej; 2 - Horný dlhovský rybník; 3 - Dolný dlhovský rybník.

Abb. 5. Zwei Teichdämme nordöstlich von der Gemeinde Dlhá an einem namenlosen Zufluss des Baches Podhájský potok und Überrest des Teichdammes in der Nachbargemeinde Košolná auf der 2. militärischen Kartierung. Die Überreste der Teichdämme sind mit Pfeilen gekennzeichent. 1 - Teich in Košolná; 2 - Oberer Langendorfer Teich; 3 - Unterer Langendorfer Teich.

\section{Rybník na potoku Parná}

V roku 1543 sa v urbári červenokamenského panstva spomínal rybník v Košolnej pod názvom Gesseldorff teücht (Marsina 1959, 157). Ked’že cez obec Košolná pretekal len jeden vodný tok - potok Parná, musel byt' rybník vybudovaný priamo na ňom. Podl’a P. Jedlicsku, ktorý sa zaoberal rybnikárstvom na červenokamenskom panstve, mal tento rybník rozlohu 52-54 jutár, teda približne 30 ha (Jedlicska 1869, 460). Od svojho vzniku patril k najvýnosnejším rybníkom 
na panstve. Potvrdzuje to predovšetkým výška príjmov za predané ryby. V roku 1539 sa získalo predajom tohoročného úlovku vyše 1068 florénov, no už o rok príjmy klesli takmer o polovicu (vyše 600 florénov) (Skladaný 1965, 41). Túto cenovú hladinu si zachovali až do roku 1586, kedy je poslednýkrát zaznamenaný údaj o výlove v účtovných knihách Fuggerovcov. Po predaji panstva Mikulášovi Pálfymu tento rybník ešte existoval - lovilo sa v ňom v rokoch 1669 a 1676 (Mišúth 2012, 91). Ďalší osud rybníka je tak vd’aka absencii účtovnej evidencie o výlove neistý.

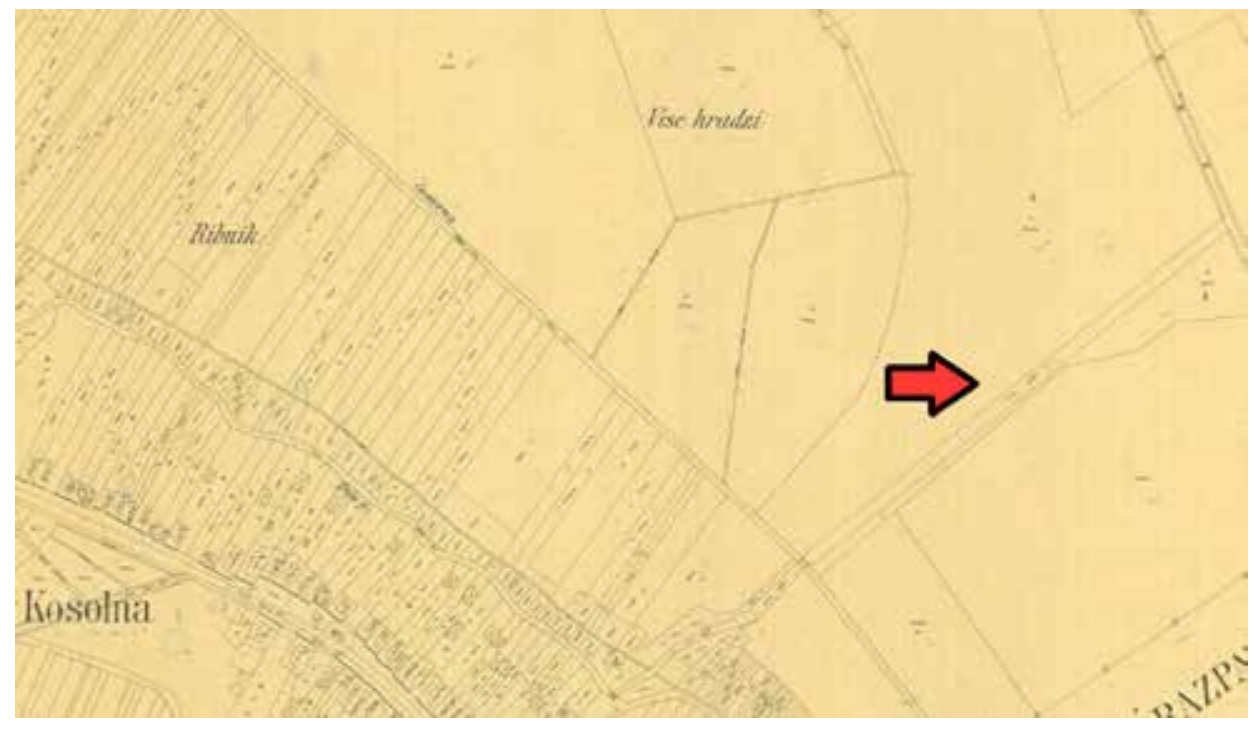

Obr. 6. Katastrálna mapa obce Košolná z roku 1907 s polohami „Ribnik“ a „Vise hradzi“, ktoré identifikujú polohu bývalého rybníka. Cesta z obce smerom na severovýchod (označená šípkou) vedie po telese rybničnej hrádze.

Abb. 6. Katasterkarte der Gemeinde Košolná aus dem Jahr 1907 mit den Flurlagen „Ribnik“ (,Teich“) und „Vise hradzi“ (,Über dem Damm“), welche die Lage des ehemaligen Teiches identifizieren. Der aus der Gemeinde in nordöstlicher Richtung führende Weg (mit Pfeil gekennzeichnet) führt am Dammkörper des Teiches entlang.

Na mape Prešporskej stolice z roku 1735 už v blízkosti obce Košolná nebol zachytený žiadny rybník, čo naznačuje, že musel zaniknút' niekedy pred koncom prvej polovice 18. storočia (obr. 4). Prvé vojenské mapovanie z rokov 1782-1784 však zachytilo hrádzu začínajúcu priamo v obci Košolná, ktorá odtial'to pokračovala smerom ku ceste spájajúcej Suchú nad Parnou a Horné Orešany. Na mape 2. vojenského mapovania dosahovala dížka zachovanej hrádze $490 \mathrm{~m}$ (obr. 5). Existenciu rybníka na tomto mieste naznačujú dokonca i chotárne názvy Ribnik a Vise hradzi na lúkach severne od obce, čo len posilňuje tento predpoklad (MOL, Kataszteri; obr. 6). Dnes sa zo spomínaného rybničného násypu zachoval len 400-metrový úsek. V súčasnosti vedie po korune tohto násypu cesta z obce Košolná smerom ku majeru Domovina (obr. 7, 8). Zánik rybníka v Košolnej s vel'kou pravdepodobnost'ou spadá do obdobia medzi rokmi 1676 (posledný doložený výlov) a 1735.

\section{Rybníky na potoku Gidra a jej prítokoch}

Asi najprepracovanejšia a najkomplikovanejšia rybničná sústava sa podla urbára červenokamenského panstva z roku 1543 nachádzala na potoku Gidra a jej prítokoch v bezprostrednej blízkosti Budmeríc (obr. 9). Malo tu byt' vybudovaných až pät rybníkov - Fančalský rybník, Dolný budmerický rybník a tri Schönauské rybníky. 


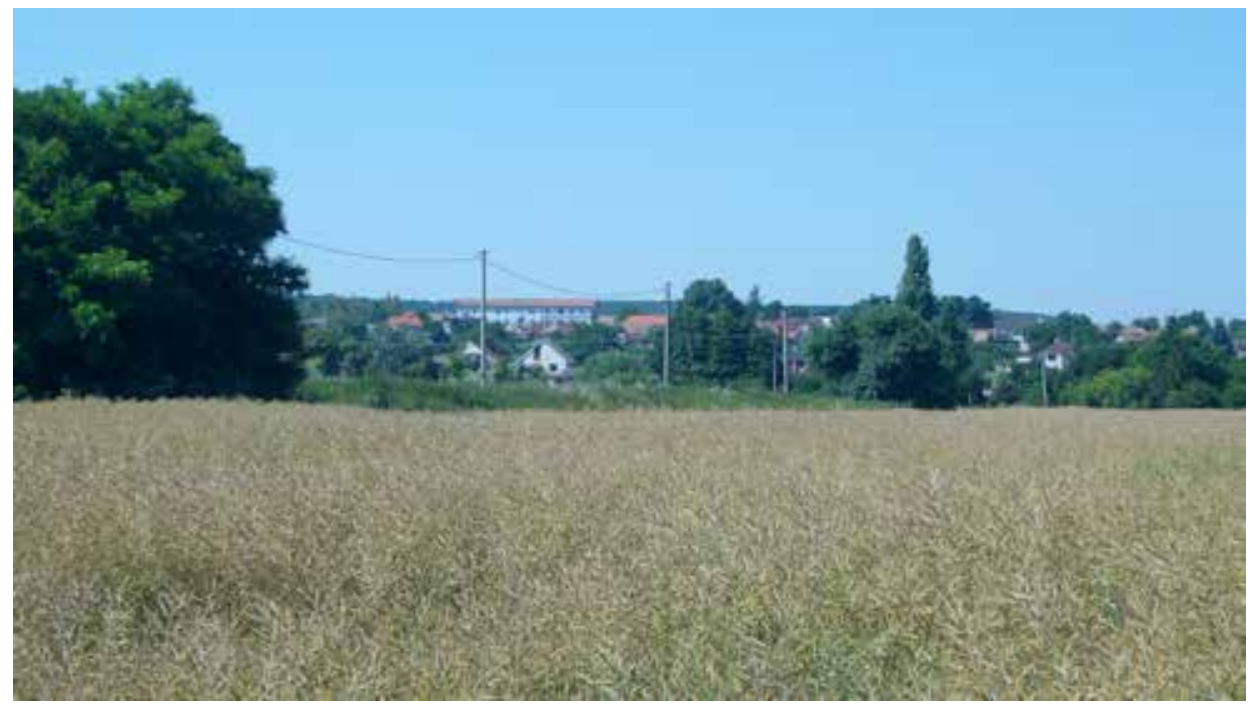

Obr. 7. Relikt rybničného násypu bývalého rybníka v Košolnej (východne od obce Košolná). Elektrické stĺpy stoja na korune bývalej hrádze. Pole pred rybničným násypom predstavuje bývalú vodnú plochu rybníka.

Abb. 7. Relikt der Teichböschung des ehemaligen Teiches in Košolná (östlich von der Geimeinde Košolná). Die Strommasten stehen auf der Krone des ehemaligen Dammes. Das Feld vor der Teichböschung stellt die ehemalige Wasserfläche des Teiches dar.

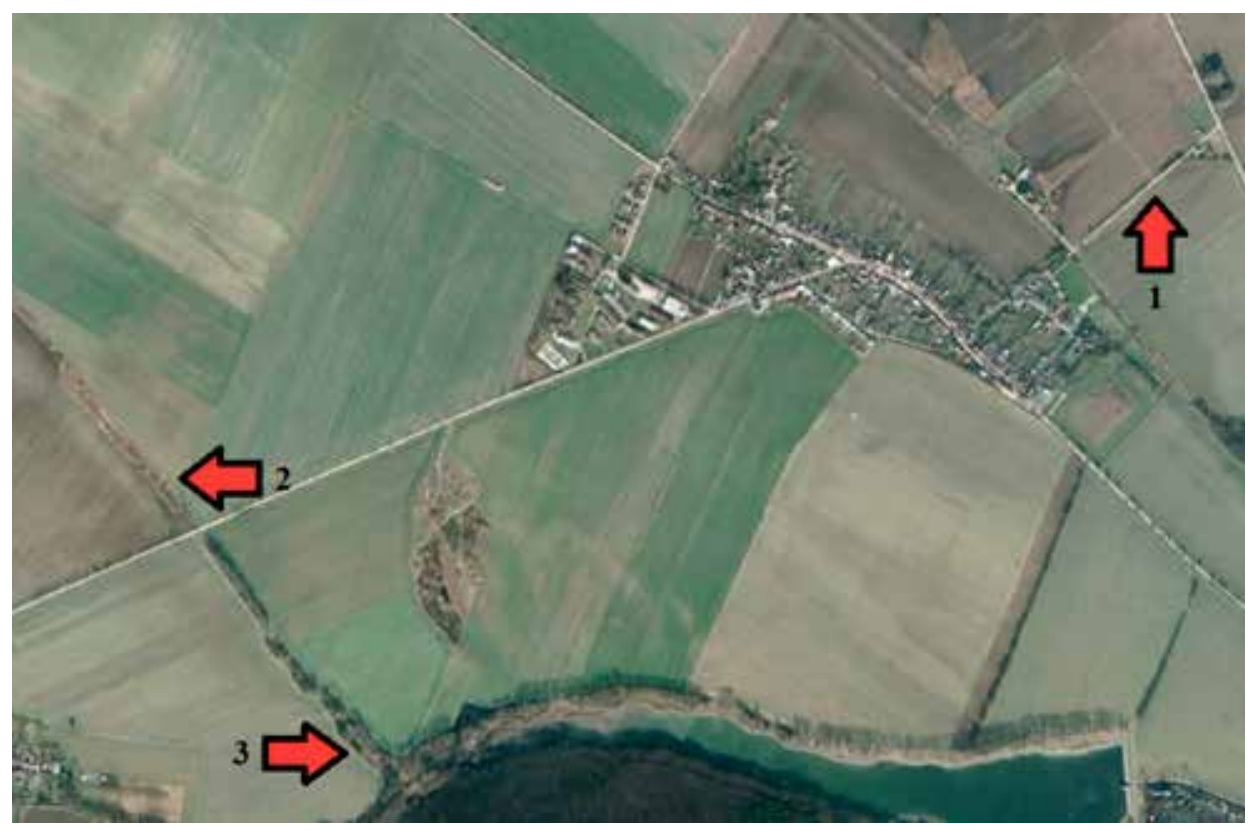

Obr. 8. Predpokladaná poloha dvoch dlhovských rybníkov a rybníka v Košolnej na leteckej fotografii. 1 - rybník v Košolnej; 2 - Horný dlhovský rybník; 3 - Dolný dlhovský rybník.

Abb. 8. Mutmaßliche Lage der beiden Langendorfer Teiche und des Teiches in Košolná auf einer Luftaufnahme. 1 - Teich in Košolná; 2 - Oberer Langendorfer Teich; 3 - Unterer Langendorfer Teich. 
Fančalský rybník, pomenovaný podl’a dediny v severovýchodnom susedstve Budmeríc, bol v spomínanom urbári uvedený ako Fanntzeldorffer Teücht (Marsina 1959, 157). Výlov rýb tu bol však zachytený už v roku 1540, teda pred spísaním samotného urbára. Ďalšie výlovy nasledovali v rokoch 1573, 1576, 1581 a 1585 (Skladaný 1965, 40-41). Rok prvého zaznamenaného výlovu naznačuje, že vznik rybníka možno klást' ešte pred príchod Fuggerovcov na červenokamenské panstvo. Potvrdzuje to listina z roku 1490, v ktorej sa popri kúpe Horného Fančala svätojurskými a pezinskými grófmi spomínal akýsi rybník (Tibenský 1998, 111). Nepochybne išlo o Fančalský rybník. Skutočnost', že sa tento rybník spomínal ešte pred kúpou panstva Fuggerovcami, potvrdzuje predpoklad o existencii rybnikárstva na panstve už koncom stredoveku. Predpokladané obdobie jeho zániku je dost' široké. Ohraničuje ho rok posledného známeho výlovu rýb (1585) a vydanie mapy Prešporskej stolice (1735).

Ako už zo samotného názvu vyplýva, priamo v katastri Budmeríc sa nachádzal Dolný budmerický rybník. Urbár z roku 1543 ho uvádzal pod menom Unnder Pomeritzer Teuch (Marsina $1959,157)$. Okrem už spomenutých výlovov z rokov 1541, 1574 a 1584 však o ňom nie sú žiadne dobové zmienky.

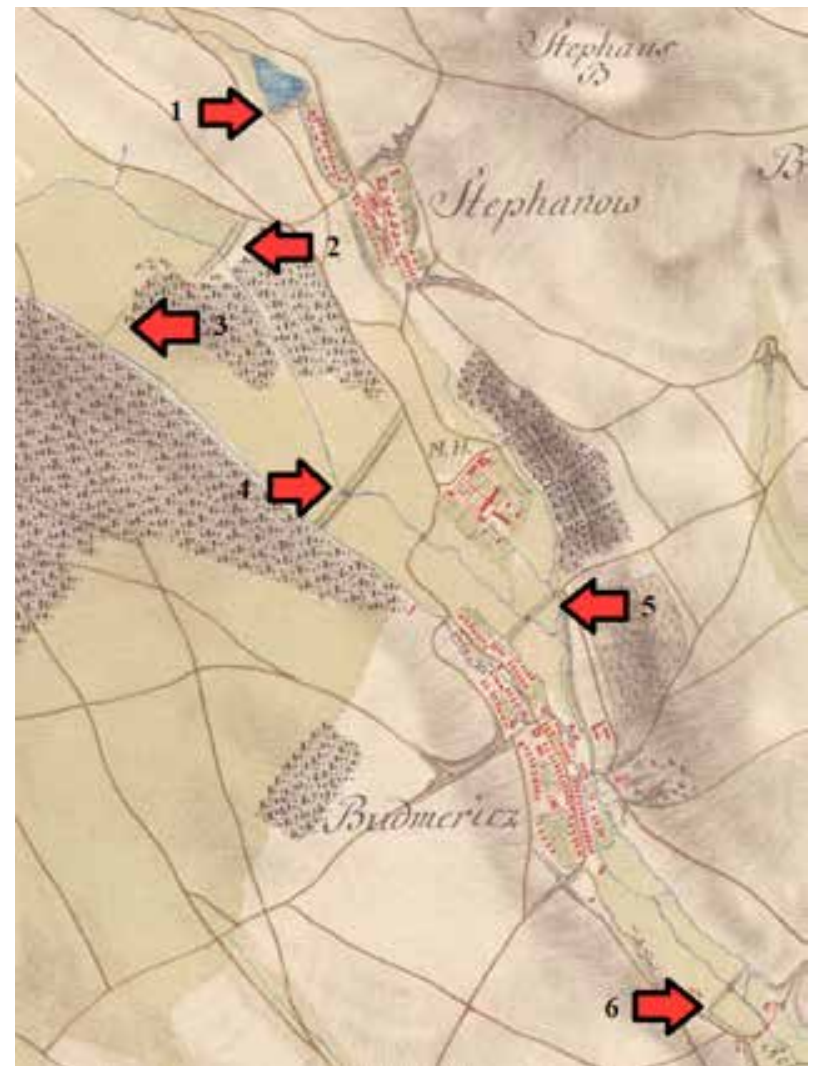

Obr. 9. Sústava rybníkov na Gidre a jej prítokoch na 1. vojenskom mapovaní. Š́pky označujú prítomnost' rybničných hrádzí po existujúcich či bývalých rybníkoch. 1-3 - Horný schönauský rybník, Dolný schönauský rybník a neznámy rybník, presné stotožnenie nie je známe; 4 - Nový schönauský rybník; 5 - Fančalský rybník; 6 - Dolný budmerický rybník.

Abb. 9. Teichsystem an der Gidra und ihren Nebenflüssen auf der 1. militärischen Kartierung. Die Pfeile kennzeichnen die Teichdämme von existierenden bzw. ehemaligen Teichen. 1-3 - Oberer Schönauer Teich, Unterer Schönauer Teich und unbekannter Teich, eine genaue Identifizierung ist nicht bekannt; 4 - Neuer Schönauer Teich; 5 - Fančal-Teich; 6 - Unterer Teich von Budmerice. 
Poslednými známymi rybníkmi v povodí Gidry je trojica schönauských rybníkov. Tie získali svoje pomenovanie podla dediny Schönau, ktorá sa nachádzala v priestore medzi dnešnými Budmericami a Častou (MOL, DL). V roku 1535 bola však dedina Schönau spomínaná už ako pustá (Žudel 1970, 19; Hrubý 2015, 107). Musela teda zaniknút' niekedy pred týmto rokom. Istotne však existovala v roku 1440, kedy bola predmetom donácie uhorskej král’ovnej Alžbety. To ohraničuje dobu jej zániku približne na jedno storočie (MOL, DL a). Hoci samotná dedina zanikla, nestalo sa tak v prípade jej mena. Názov Schönau sa preniesol na (dnešnú) dedinu Štefanová, ktorá bola $\mathrm{v}$ jej blízkosti založená $\mathrm{v}$ roku 1588. Toto pomenovanie sa dlho neudržalo, no odrazilo sa v názve troch rybníkov v susedstve Štefanovej. Tie, hoci neskôr ležali v tesnej blízkosti spomínanej obce, dostali pomenovanie práve po zaniknutej dedine Schönau (Jedlicska 1882, 285). Pod týmto názvom sa objavili v urbári červenokamenského panstva z roku 1543 ako Oberschonawer teüch, Unnterschonawer a Newschönawer teuch. Už podl'a názvu je zrejmé, že najmladším z trojice rybníkov bol Nový schönauský rybník (Newschönawer teuch). Podl’a záznamov v účtovnej knihe červenokamenského panstva z rokov 1539-1542 sa mal tento rybník v čase spísania knihy ešte len budovat' (Skladaný 1965, 32, 37). V urbári červenokamenského panstva z roku 1543 však vystupoval medzi ostatnými rybníkmi ako dokončený (Marsina 1959, 157).

Zápis v urbári z roku 1559 poskytuje len obmedzenú výpovednú hodnotu o schönauských rybníkoch. Síce tu neboli spomenuté pod svojím pôvodným menom, no v súvislosti s obcou Budmerice boli v rámci jej chotára uvedené tri nemenované rybníky. Sem však mohol byt' zahrnutý aj Dolný budmerický rybník či Fančalský rybník (Benková 2012, 210). Podl’a účtovných kníh panstva sa Nový schönauský rybník v roku 1585 ešte používal (Skladaný 1965, 42). Počiatok Dolného (Unnter-) a Horného (Ober-) schönauského rybníka zostáva zatial' neobjasnený. Nie je vylúčené, že na panstve existovali už pred príchodom Fuggerovcov.

Úroveň presnosti lokalizácie konkrétnych rybníkov v povodí Gidry je v dôsledku ich väčšieho počtu a rôznej pramennej bázy vel’mi rôznorodá. Najmenej problémová je lokalizácia

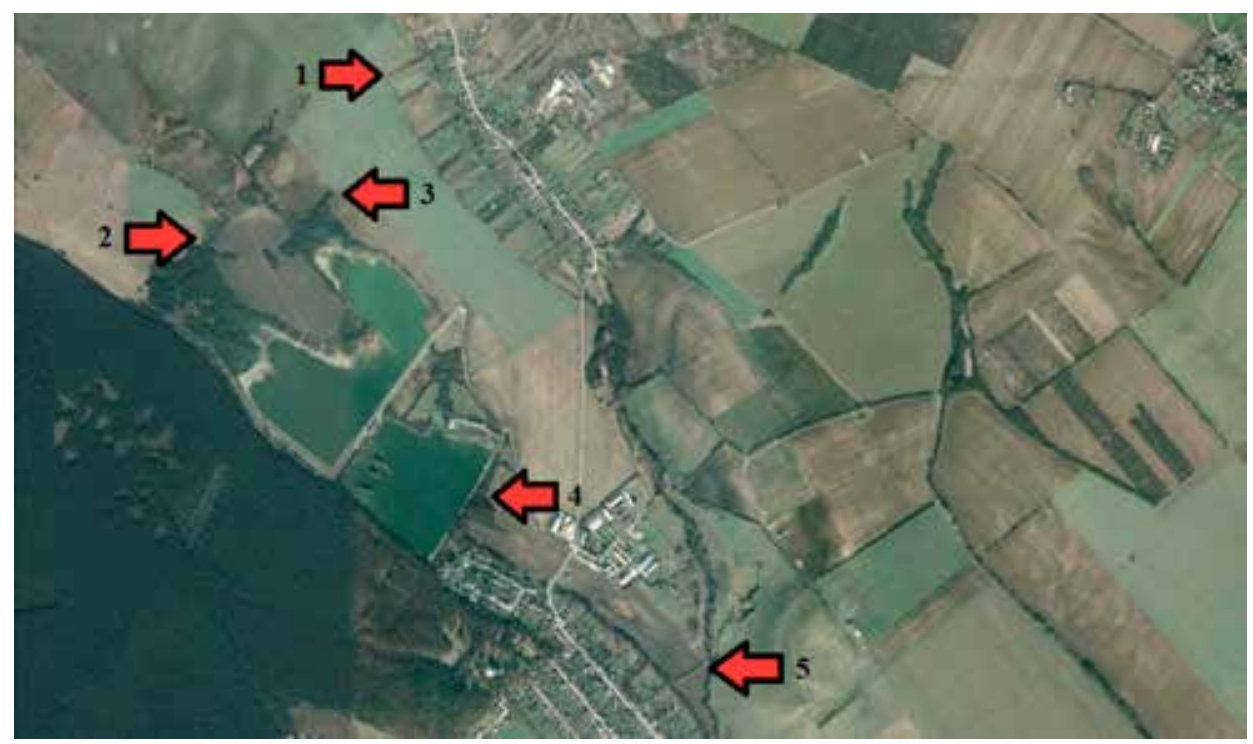

Obr. 10. Sústava rybníkov na Gidre a jej prítokoch na leteckej fotografii. Šípky označujú prítomnost' rybničných hrádzí po existujúcich či bývalých rybníkoch. 1-3 - Horný schönauský rybník, Dolný schönauský rybník a neznámy rybník, presné stotožnenie nie je známe; 4 - Nový schönauský rybník; 5 - Fančalský rybník.

Abb. 10. Teichsystem an der Gidra und ihren Nebenflüssen auf einer Luftaufnahme. Die Pfeile kennzeichen die Teichdämme von existierenden bzw. ehemaligen Teichen. 1-3 - Oberer Schönauer Teich, Unterer Schönauer Teich und unbekannter Teich, eine genaue Identifizierung ist nicht bekannt; 4 - Neuer Schönauer Teich; 5 - Fančal-Teich. 
Fančalského rybníka (obr. 10). Tá je dnes ul'ahčená nielen vd’aka písomným prameňom, no i archeologickým výskumom, ktorý na severovýchodnom okraji Budmeríc prebehol v 70. rokoch 20. storočia (Egyházy-Jurovská 1980, 39-61). V priebehu neho sa podarilo objavit' zvyšky pôvodnej stredovekej dediny Fančal, ktorá sa rozkladala na l’avom brehu Štefanovského potoka. Ked’že pri kúpe Fančala v roku 1490 sa spomínal akýsi rybník, musel sa s určitostou nachádzat' západne odtial'to. Je to priestor, kde sa k sebe približujú toky Štefanovského potoka a Gidry. Z hladiska stavby rybníka to bolo vhodné miesto. Potvrdzuje to i pohl'ad na 1. a 2. vojenské mapovanie $-\mathrm{v}$ uvedenom priestore je $\mathrm{v}$ extraviláne Budmeríc zretel'ný násyp po pôvodnej hrádzi, ktorý v teréne existuje dodnes. Po jeho chrbte vedie pol’ná cesta $\mathrm{k}$ majeru Horný dvor. Zvyšok násypu dnes meria okolo $200 \mathrm{~m}$. Pôvodne však dosahoval ovel’a väčšiu dížku. Ramená hrádze totiž chránili pred zaplavením cestu z Budmeríc do Štefanovej a komunikáciu spájajúcu intravilán Budmeríc s Fančalským majerom.

Ked’že rybníky na sever od Budmeríc niesli názov podla zaniknutej dediny Schönau (Nový schönauský rybník mal zasahovat' do severnej časti katastra Budmeríc) či blízkeho Fančalského majera (hrádza Fančalského rybníka sa bezprostredne dotýkala záhrad intravilánu Budmeríc), jediný priestor, kde by mohol byt' umiestnený Dolný budmerický rybník, poskytovalo okolie Gidry južne od Budmeríc. Tak ako Fančalský rybník, nebol na mape Prešporskej stolice z roku 1735 zachytený ani Dolný budmerický rybník. Dôvodom môže byt' skoré obdobie jeho zániku, hoci ten sa dá ohraničit' len rokom jeho posledného výlovu (1584) a zhotovením Mikovíniho mapy Prešporskej stolice. Pohl'ad na 1. vojenské mapovanie však potvrdil predpoklad o jeho prítomnosti práve v týchto miestach. V blízkosti bývalého majera a tehelne v polohe Silnica sa po oboch brehoch Gidry rozkladal násyp tvoriaci relikt po rybničnej hrádzi (obr. 9). Dnes ho však už na tomto mieste nevidno. Jeho hypotetickým pozostatkom môže byt' terénna vlna viditel'ná medzi bývalým hliníkom a potokom Gidra.

Najproblematickejšie určenie polohy je spojené s trojicou schönauských rybníkov. S istotou sa museli rozkladat' v priestore medzi dnešnými Budmericami, Častou a Štefanovou, kam je lokalizovaná zaniknutá dedina Schönau. Istú indíciu na určenie ich polohy poskytuje zápis v urbári z roku 1543. Pri uvádzaní rybníkov autor súpisu postupoval vždy od najvyššie položeného rybníka po nižšie položené. Možno predpokladat, že rovnaký postup zvolil i v prípade schönauských rybníkov. Najvyššie položeným rybníkom by tak mal byt' Horný schönauský rybník, nasledovaný Dolným schönauským rybníkom. Ďalej nižšie po toku by sa mal nachádzat' Nový schönauský rybník. Sledovaný priestor predpokladanej lokalizácie troch schönauských rybníkov je možné porovnávat' na viacerých mapových zobrazeniach. Prvé grafické znázornenie tejto plochy poskytuje mapa Bratislavskej stolice v rámci Belových Notícií z roku 1735 (obr. 4). V severnom susedstve Budmeríc je však v tomto období možno vysledovat' len dva rybníky - jeden tesne na severozápad od Budmeríc, druhý na potoku západne od Štefanovej. Ak rešpektujeme zistenie, že súpis rybníkov v urbári z roku 1543 postupoval od vyššie k nižšie položeným rybníkom, tak rybník v severozápadnom susedstve Budmeríc možno stotožnit' s Novým schönauským rybníkom. Nižšie po toku Gidry už jeho umiestnenie ani nebolo možné, pretože tu sa už nachádzal Fančalský rybník. V čase realizácie 1. vojenského mapovania už Nový schönauský rybník neexistoval. Zretel’ne je tu však viditel’ný jeho relikt vo forme hrádze. Plocha bývalého Nového schönauského rybníka sa ako jediná z červenokamenských rybníkov dočkala opätovného využitia. Dnes sa na jeho mieste nachádza rybník Hájiček, ktorého čelnú hrádzu tvorí čiastočne pôvodný násyp Nového schönauského rybníka (obr. 11). Dížka násypu na 2. vojenskom mapovaní dosahovala približne 400 m. Rybník musel zaniknút' medzi rokmi 1768 a $1782-1784$.

Druhý rybník, lokalizovaný na Mikovíniho mape západne od Štefanovej, bol pôvodne interpretovaný ako Horný schönauský rybník (Neumann 2016, 194-195). Vychádzalo sa pritom z údajov urbára z roku 1559 a z historického vývoja budmerického katastra. V tomto urbári sa $\mathrm{v}$ rámci Budmeríc bez bližšej špecifikácie spomínali tri rybníky. S istotou sa dalo konštatovat', že k nim patril Dolný budmerický rybník, v ktorom boli zaznamenané výlovy rýb v rokoch 1541, 1574 a 1584 (Skladaný 1965, 40). Rovnako medzi troma rybníkmi bolo možné identifikovat’ aj 


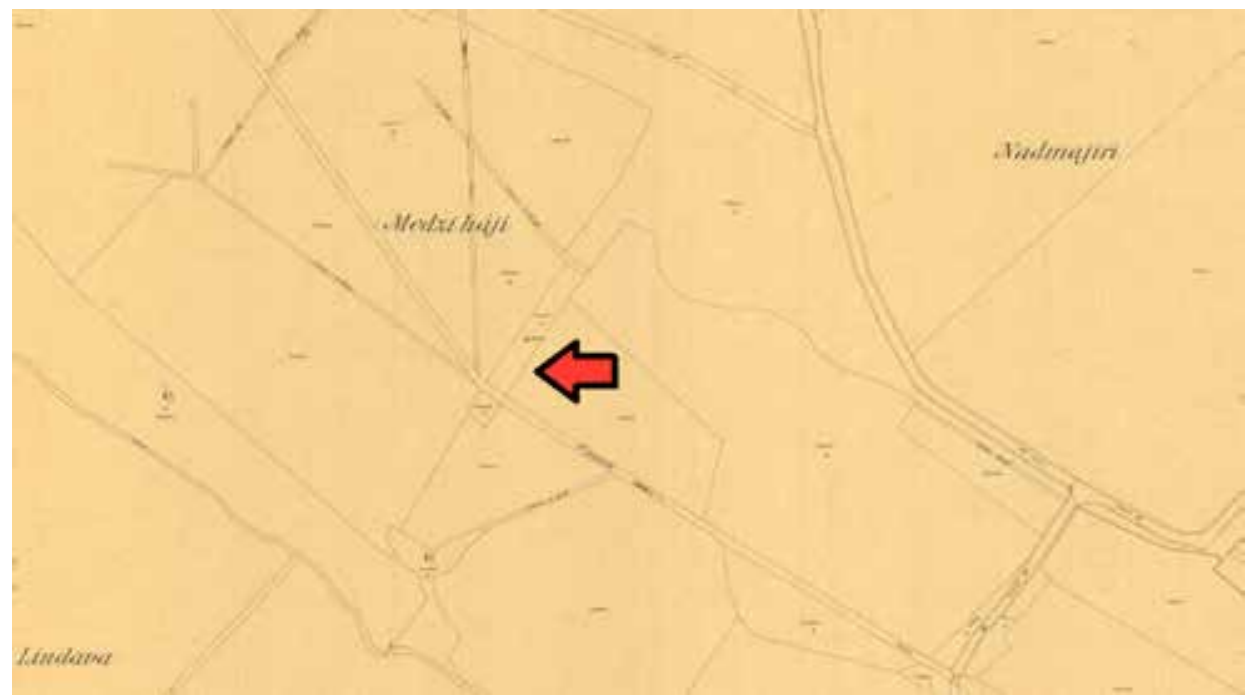

Obr. 11. Teleso hrádze Nového schönauského rybníka zachytené na katastrálnej mape obce Budmerice z roku 1904. Abb. 11. Dammkörper des Neuen Schönauer Teichs auf einer Katasterkarte der Gemeinde Budmerice aus dem Jahr 1904.

Nový schönauský rybník, vybudovaný v rokoch 1539-1542, z ktorého boli zaznamenané výlovy v rokoch 1573, 1580 a 1585 (Skladaný 1965, 42). Otázkou bolo, ktorý rybník bol posledným zo spomenutej trojice - Fančalský, Horný alebo Dolný schönauský rybník? Prvý z nich vylučoval pohlad na vývoj budmerického chotára. Ten sa do svojej definitívnej podoby formoval na prelome 15. a 16. storočia. Vznikol zlúčením budmerického chotára, rozkladajúceho sa na pravom brehu Gidry, hornofančalského a dolnofančalského chotára, ktoré sa nachádzali východne od Gidry (Žudel 1970, 19-38). Dôležité pritom bolo, že územie budúceho fančalského rybníka a majera prináležalo k bývalému Hornému Fančalu. Dokonca aj po pripojení jeho chotára k Budmericiam si zachoval svoju samostatnost', nakol'ko sa počítalo s obnovením dediny, ktorá tu zanikla niekedy medzi rokmi 1528-1532 (Žudel 1970, 27). Obyvatelia Budmeríc preto nevnímali stavbu Fančalského rybníka a majera ako zásah do svojich práv, ked’že oba ležali v katastri bývalého Horného Fančala. Inak to bolo pri stavbe Nového schönauského rybníka, ktorý sa už v budmerickom chotári nachádzal. Neustále námietky a st’ažnosti Budmeričanov museli majitelia panstva vyriešit až majetkovým vyrovnaním vo forme lúk v katastri susednej obce Dubová (Žudel 1970, 32). Ako jediné teda prichádzali do úvahy Horný a Dolný schönauský rybník. Ked'že na 1. vojenskom mapovaní (obr. 9) bolo možné vidiet' existujúci rybník na severnom okraji Štefanovej a hrádzu - relikt po bývalom rybníku západne od tej istej obce, automaticky bol prvý (severnejšie položený) rybník stotožnený s Horným schönauským rybníkom, zatial' čo druhý bol identifikovaný ako Dolný schönauský rybník (Neumann 2016, 194-195). Pri terénnom prieskume v roku 2018 bol však v blízkosti bývalej rybničnej hrádze západne od Štefanovej objavený ešte d’alší, svojimi rozmermi takmer totožný zemný násyp (obr. 12). Vyvstáva tak otázka, ktorý z troch predpokladaných rybníkov bol pôvodne Horným a Dolným schönauským rybníkom. Rovnako sa ponúka otázka, prečo v tomto priestore nespomínali červenokamenské urbáre a účtovné knihy tretí rybník - išlo o mladšiu stavbu, ktorú uvedené historické pramene nemali vôbec možnost' zachytit', alebo ide v tomto prípade skôr o nedôslednost' ich autorov? Prikláňame sa skôr k prvej možnosti. Nech už bol však Dolný schönauský rybník ktorýkol'vek zo sledovaných terénnych reliktov, $\mathrm{s}$ istotou zanikol niekedy $\mathrm{v}$ druhej polovici 16. storočia, určite však pred rokom 1574 (Skladaný 1965, 31). Existencia zvyšných dvoch schönauských rybníkov - Nového a Horného (alebo len jedného z nich spoločne s novším rybníkom vybudovaným severne od 
Štefanovej) je doložená zápisom v urbári mestečka Častá z roku 1768. Na otázku, aké škody musia trpiet' miestni obyvatelia, títo odpovedali: „Skrs Ribniki take sskodu trpime, neb kdiš guš zbosu bi uffami bilo, s tich gistich Ribniku mhla vinde a v tem zbošu sskodu učini“" (Urbar 1768, 48). Z toho jasne vyplýva, že ešte na začiatku roku 1768 existovali v blízkosti chotára Častej rybníky, ktoré ničili úrodu. Ked’že v urbári boli spomenuté „ribniki“, museli v dobe spísania urbáru existovat' minimálne dva.

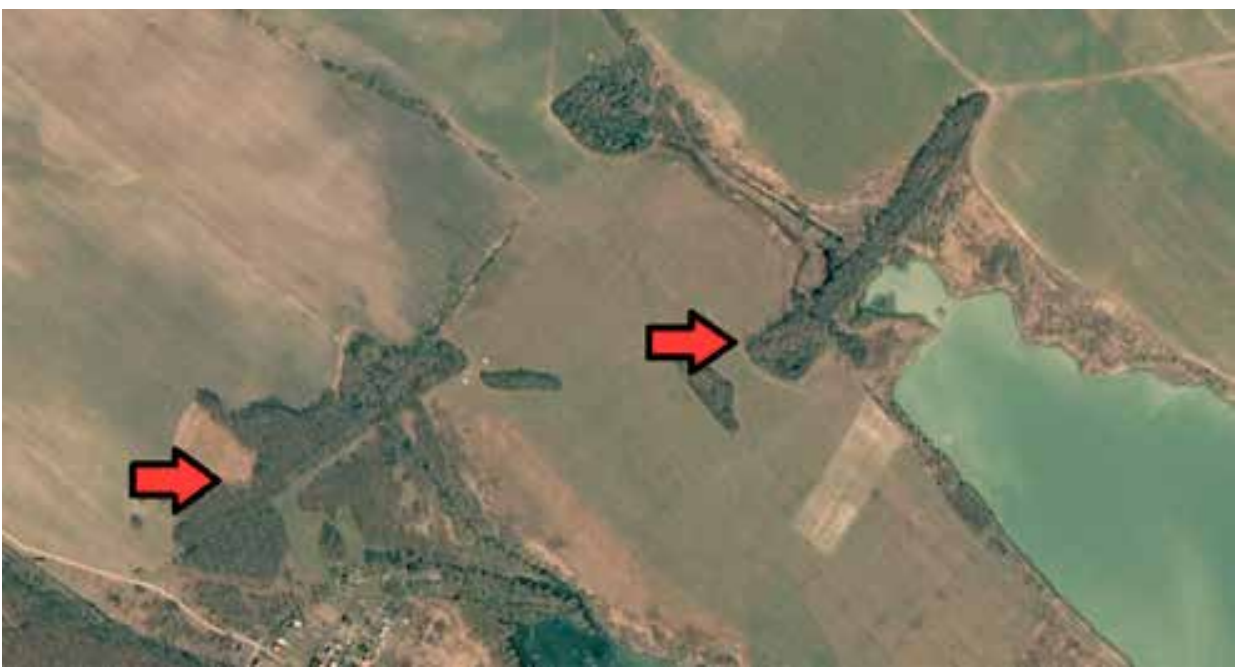

Obr. 12. Letecká fotografia dvoch reliktov rybníkov severozápadne od Budmeríc. Oba sú dnes zarastené stromovým porastom. Š́́pky ukazujú na relikty rybničných hrádzí.

Abb. 12. Luftaufnahme von zwei Teichrelikten nordwestlich von Budmerice. Beide sind heute von dichtem Wald bedeckt. Die Pfeile zeigen auf Teichdammrelikte.

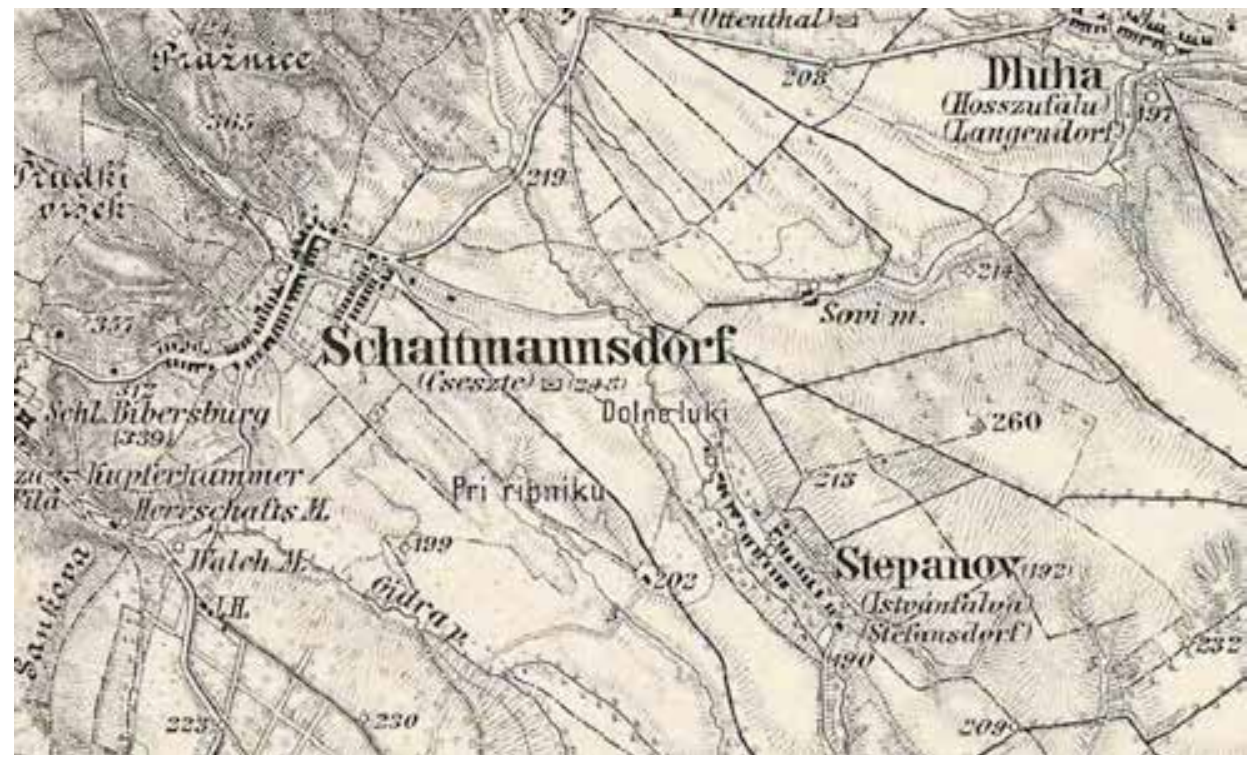

Obr. 13. Miestny názov „Pri ribniku“ na 3. vojenskom mapovaní naznačuje prítomnost' rybníka na pomedzí katastrov obcí Častá, Štefanová a Budmerice.

Abb. 13. Der Flurname „Pri ribniku“ („Am Teich“) auf der 3. militärischen Kartierung deutet auf die Existenz eines Teiches an der Katastergrenze der Gemeinden Častá (Schattmansdorf), Štefanová (Stefansdorf) und Budmerice (Pudmeritz) hin. 
Na prítomnost' jedného z nich poukazujú i pomiestne názvy Tó mögötti (Za rybníkom) a Tó melletti (Pri rybníku), respektíve poloha Pri ribniku na mape 3. vojenského mapovania (obr. 13). Obe polohy sa nachádzajú v južnej časti chotára obce Častá na hranici s budmerickým katastrálnym územím. Určitú vypovedaciu hodnotu o vel'kosti tunajšieho rybníka by mohol poskytovat' tvar a priebeh hranice katastra oboch spomínaných obcí. Dlhý úzky výbežok budmerického katastra smerom na sever mohol kopírovat’ pobrežnú líniu rybníka, ktorý patril do katastra obce. Zohl'adniac približne $400 \mathrm{~m}$ dlhý priehradný násyp viditel'ný ešte na 1 . vojenskom mapovaní, je možné odhadovat' plochu rybníka na 18 ha.

\section{Rybníky na Vištuckom potoku}

Pri obci Vištuk sa nachádzali v čase spísania urbára z roku 1543 dva rybníky - Horný a Dolný vištucký rybník. Ober Wischtuecher teüch, teda Horný vištucký rybník mal ležat' západne od Vištuku v údolí, cez ktoré preteká Dubovský a Vištucký potok (Marsina 1959, 157). Podl’a P. Jedlicsku sa rybník tiahol popri chotárnej hranici Vištuku a Dubovej. Jeho rozloha mohla dosahovat' až 140 jutár (vyše 80 ha), čo z neho robilo najväčší rybník na červenokamenskom panstve (Jedlicska 1869, 461). Urbár z roku 1559 spomínal taktiež dva rybníky. V čase jeho spísania však tam jeden z nich nebol (unus est deesta), hoci v nasledujúcom období máme z oboch vištuckých rybníkov doložené výlovy rýb (Benková 2012, 206). Mohlo by to naznačovat', že jeden rybník bol vypustený za účelom jeho pravidelnej údržby. Ján Dubravius vyslovene spomína, že rybníky je nutné po 8 až 10 rokoch obnovovat'. Táto obnova spočívala v jeho vypustení a ponechaní ho minimálne na 1 rok úhorom. Počas neho sa mohli na rovnakom mieste pestovat' obilniny a žat' seno, čo revitalizovalo pôdu (Dubravius 1953, 70). Po tom, čo pôda znova načerpala silu, mohol sa rybník znova napustit'. Starostlivost' o tak vel'ký rybník bola pravdepodobne vel'mi náročná. Aj výnosy z jeho výlovov z rokov 1576 a 1578 boli vel'mi nízke v porovnaní s ovel’a menšími rybníkmi (Skladaný 1965, 42). Pravdepodobne to viedlo k prehodnoteniu d'alšieho využívania tak rozsiahleho rybníka. Niet divu, že rybník sa neobjavuje na Mikovíniho mape, tak ako ani na všetkých vojenských mapovaniach.

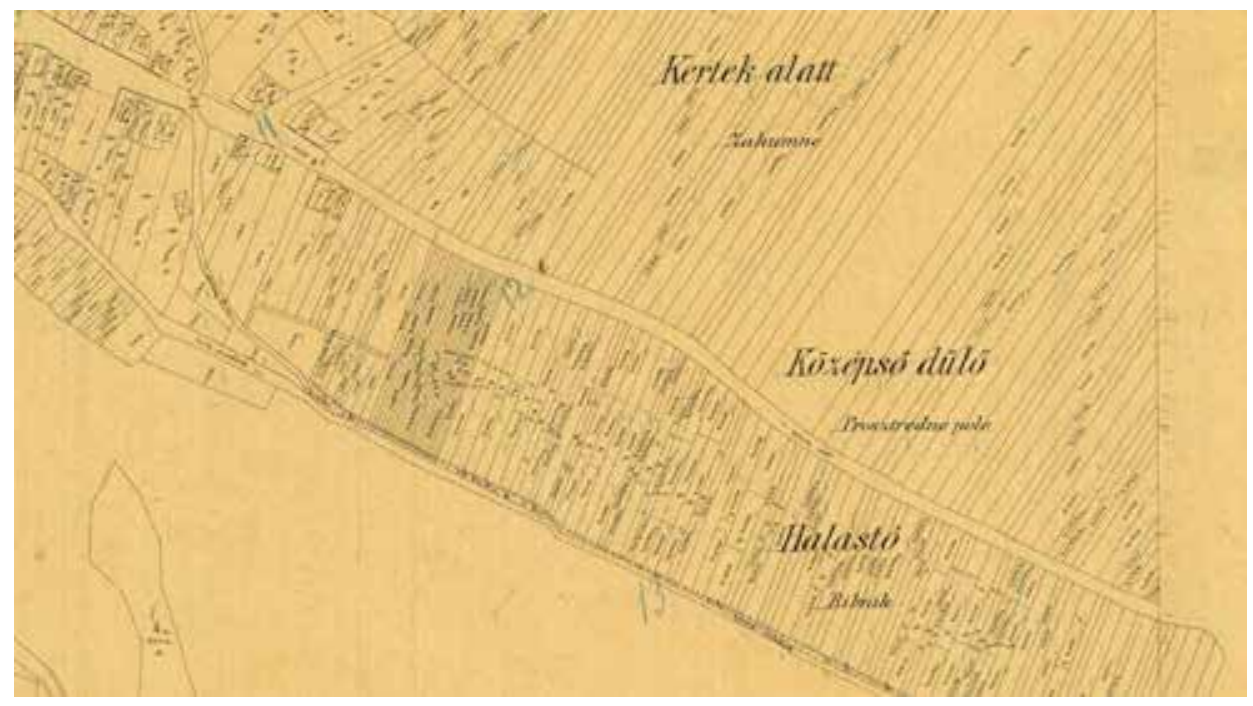

Obr. 14. Prítomnost’ Dolného vištuckého rybníka naznačuje poloha s názvom „Halastó“- Ribnik na katastrálnej mape obce Vištuk z roku 1907.

Abb. 14. Die Existenz des Unteren Vištuker Teiches wird angedeutet durch die Lage mit dem ungarischen Flurnamen „Halastó“ („Teich“) auf einer Katasterkarte der Gemeinde Vištuk (Wischtuk od. Wischteich) aus dem Jahr 1907. 
Druhým vištuckým rybníkom bol Unter Wischtüecher teücht - Dolný vištucký rybník, ležiaci na Vištuckom potoku južne od obce smerom na Báhoň, čo potvrdzuje aj názov polohy $\mathrm{Ha}$ lastó - Ribnik na katastrálnej mape z roku 1907 (Marsina 1959, 157; MOL, Kataszteri a; obr. 14). Jeho rozloha činila 20 jutár, teda vyše 10 ha (Jedlicska 1869, 461). Posledný zaznamenaný výlov rýb sa uskutočnil v roku 1580 (Skladaný 1965, 42). Odvtedy stopy po ňom miznú.

Ked’že Horný vištucký rybník nebol zachytený na žiadnom mapovaní, aj jeho lokalizácia môže byt' pochybná. Ak je možné sa pridržiavat' informácií od P. Jedlicsku, tento rybník sa nachádzal na katastrálnej hranici Vištuku a Dubovej. Pozostatok vo forme rybničného násypu sa po tomto rybníku nepodarilo v teréne identifikovat'. Opačnú situáciu možno sledovat' v prípade Dolného vištuckého rybníka. Jeho jediným pozostatkom je okolo $170 \mathrm{~m}$ dlhá hrádza, ktorú je možné vidiet' na 1. a 2. vojenskom mapovaní, rovnako ako aj v súčasnom teréne (obr. 15). Oba rybníky museli zaniknút' niekedy po konci 16 . storočia.

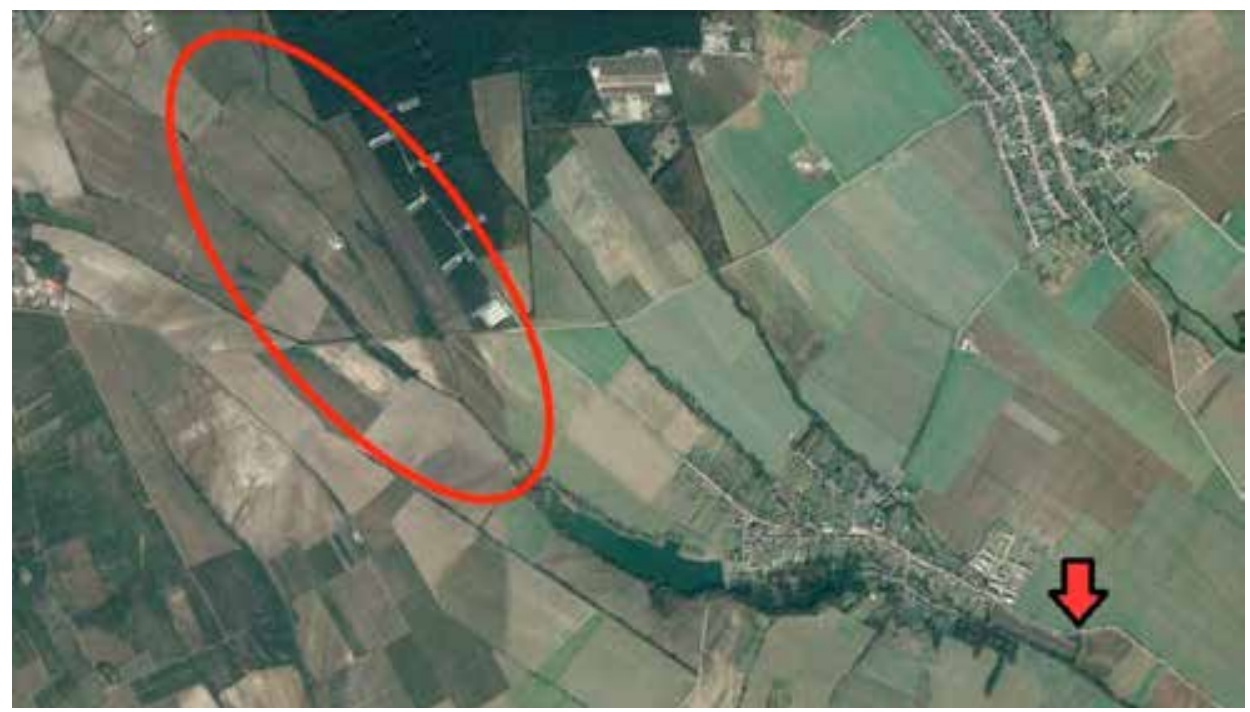

Obr. 15. Zvyšok hrádze Dolného vištuckého rybníka (označenej šípkou) na leteckom zábere. Severozápadne od obce je naznačené približné miesto rozlohou najväčšieho rybníka na červenokamenskom panstve - Horného vištuckého rybníka. Abb. 15. Überrest des Dammes des Unteren Vištuker Teiches (mit Pfeil gekennzeichnet) auf einer Luftaufnahme. Nordwestlich von der Gemeinde ist die ungefähre Lage des größten Teiches der Herrschaft Červený Kameň - des Oberen Vištuker Teiches - eingezeichnet.

\section{Rybníky na Podhájskom potoku a jeho bezmennom prítoku}

Urbár z roku 1543 uviedol v katastri obce Dlhá dva rybníky - Ober Langendorffer Streicher a Unnder Langendorffer Streicher (Marsina 1959, 157). V urbári z roku 1559 bolo uvedené, že jeden z nich práve vyschol (Benková 2012, 208). Pravdepodobne však musel byt' v krátkom čase obnovený, pretože v priebehu 70. rokov 16. storočia prebehli v oboch rybníkoch dva výlovy rýb (Skladaný 1965, 40). Oba rybníky patrili k tým menším, ktoré sa na panstve nachádzali. Ak môžeme dôverovat' údajom P. Jedlicsku, tak Horný rybník mal 10 jutár (5,8 ha) a Dolný rybník dosahoval rozlohu len 4 jutrá $(2,3$ ha) (Jedlicska 1869, 460). Poloha rybníkov nebola v urbároch explicitne uvedená.

Pohl'ad na historické mapovania celkom dobre upresňuje polohu oboch rybníkov. Na Mikovíniho mape z roku 1735 a na nej odvodených mapách boli severovýchodne od obce Dlhá zachytené dva rybníky (obr. 4). Oba sa rozkladali vo výraznom údolí medzi obcami Dlhá a Košolná, 
cez ktorý dodnes preteká bezmenný potok. Počas realizácie 1. vojenského mapovania však už tieto rybníky zjavne neexistovali. Po hornom rybníku (vy̌šsie po toku potoka) zostala len približne $100 \mathrm{~m}$ dlhá hrádza severozápadne od mosta na ceste medzi obcami Dlhá a Košolná. Stopy po Dolnom rybníku na tomto mapovaní nie sú. Približne $150 \mathrm{~m}$ dlhá hrádza Dolného rybníka sa objavuje až na 2. vojenskom mapovaní obklopená malým lesíkom (obr. 5). Tesne na severozápad od hrádze prechádza na mape cesta vedúca z Dlhej priamo do Suchej nad Parnou. Dnes sa na ich mieste nachádza trvalo premočená pôda, akékol'vek náznaky po existencii rybničných násypov neboli viditel'né ani na katastrálnej mape zo začiatku 20. storočia (obr. 16). Zánik oboch dlhovských rybníkov možno ohraničit' rokmi 1735 až 1782-1784.

Posledným rybníkom zachyteným v urbári panstva z roku 1543 je istý Schneggen teucht (Marsina 1959, 157). Na rozdiel od ostatných rybníkov nebol pomenovaný podla obce, pri ktorej sa nachádzal. Namiesto toho bol zvolený názov, ktorý mal poukazovat' na druh živočícha chovaného v rybníku. Pravdepodobne malo teda íst' o slimáky (po nemecky Schnecke), či ako spomína P. Jedlicska o rybničné korýtka (Jedlicska 1869, 461). Rybník so „slimákmi“ umiestnil P. Jedlicska na panský majer v Častej. M. Skladaný ho však na základe účtovných kníh Fuggerovcov lokalizoval do obce Dolany. Pri pohl'ade na druhy vylovených rýb sa tu však žiadne slimáky či korýtka nenachádzajú, čo vzbudzuje isté pochybnosti o jeho polohe (Skladaný 1965, 31).

Istú pomoc pri lokalizácii rybníka v Dol’anoch poskytuje katastrálna mapa obce z roku 1910 (obr. 17). Tu tesne za obcou pri ceste smerom na Častú možno identifikovat' dve chotárne

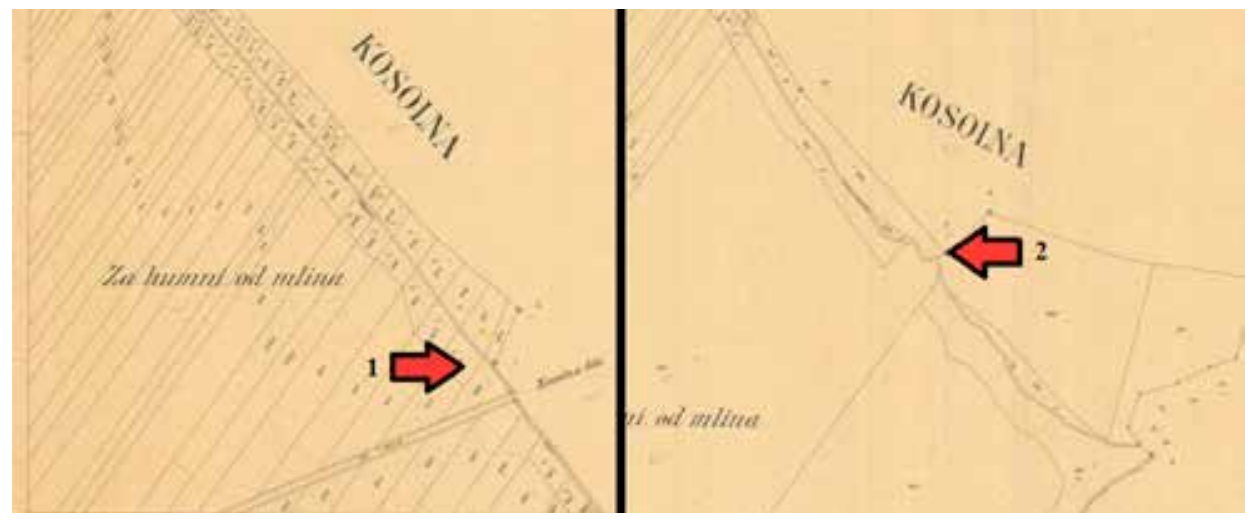

Obr. 16. Dvojica dlhovských rybníkov na katastrálnej mape obce Dlhá z roku 1909. Šípky na mape označujú približnú pozíciu dnes už neexistujúcich rybničných hrádzí. 1 - Horný dlhovský rybník; 2 - Dolný dlhovský rybník.

Abb. 16. Die zwei Langendorfer Teiche auf einer Katasterkarte der Gemeinde Dlhá aus dem Jahr 1909. Die Pfeile auf der Karte kennzeichnen die ungefähre Lage der heute nicht mehr existierenden Teichdämme. 1 - Oberer Langendorfer Teich; 2 - Unterer Langendorfer Teich.

polohy s názvami Za ribnikom a Podvorne za ribnikom (MOL, Kataszteri b). Pravdepodobne neprekvapí ani prítomnost' mlyna s vodným náhonom, ktoré sa často nachádzali pod viacerými rybníkmi na panstve. Tak ako v prípade dvoch rybníkov v Dlhej, ani v Dol’anoch už dnes nemožno v uvedených polohách identifikovat' akékol'vek stopy po prítomnosti rybníka.

Otázka doby zániku rybníka Schneggen teucht zostáva otvorená. Už v roku 1559 sa v urbári pri obci Dol'any nespomína žiadny rybník. Je tu však zmienka o potoku, ktorý bol prehradený (Benková 2012, 199). Aj napriek tomu sa tu mal konat' posledný zaznamenaný výlov rýb na jar roku 1585 (Skladaný 1965, 40). Situáciu okolo umiestnenia a trvania rybníka neosvetl'uje ani to, že na žiadnom mapovaní nie je tento údajný rybník zachytený. To neustále ponecháva otázniky nad jeho polohou v rámci červenokamenského panstva. Jeho približný zánik tak môžeme datovat' do obdobia medzi rokmi 1585 a 1735. 


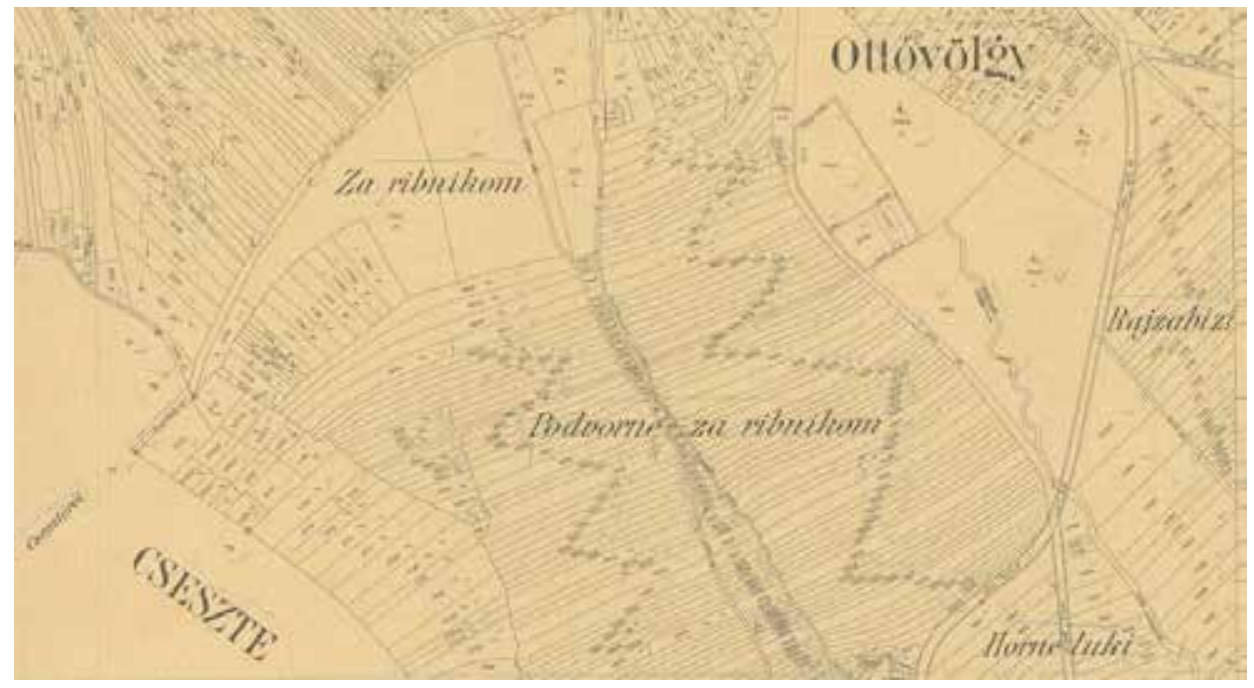

Obr. 17. Katastrálna mapa obce Dol’any z roku 1910 s polohami „Za ribnikom“ a „Podvorne za ribnikom“, ktoré môžu indikovat' polohu bývalého rybníka.

Abb. 17. Katasterkarte der Gemeinde Dol’any aus dem Jahr 1910 mit den Flurlagen „Za ribnikom“ („Hinter dem Teich“) und „Podvorne za ribnikom“ („Podvorne hinter dem Teich“), die die Lage des ehemaligen Teiches indizieren können.

\section{Záver}

Komparácia katastrálnych máp, vojenských a iných mapovaní v kombinácii s písomnými prameňmi a pokusom priamej terénnej identifikácie zaniknutých krajinných štruktúr prispela k bližšiemu osvetleniu osudu červenokamenských rybníkov od začiatku novoveku. Podarilo sa tak identifikovat' nielen širšie či užšie intervaly zániku jednotlivých rybníkov, ale vo väčšine prípadov aj ich presnú polohu v krajine. Najpresnejšie sa podarilo určit' dobu zániku v prípade dvoch dlhovských rybníkov medzi obcami Dlhá a Košolná (oba v období medzi rokmi 1755 až 1782-1784). Do obdobia vlády Márie Terézie taktiež spadá zánik Nového schönauského rybníka (1768 až 1782-1784), ktorý ako jediný bol obnovený a je využívaný dodnes. Niekedy medzi rokmi 1676 a 1735 musel zaniknút' aj vel'ký rybník pri obci Košolná, po ktorom ako jediný relikt zostal dlhý rybničný násyp východne od obce Košolná. Intervaly možného zániku ostatných rybníkov sú ovel'a rozsiahlejšie. Dolnú hranicu tvorí rok ich posledného zaznamenaného výlovu, hornou hranicou je obdobie vyhotovovania máp pre vydanie Notícií Mateja Bela z roku 1735. Možno sem zaradit' Fančalský rybník s dodnes zachovaným rybničným násypom (1585 až 1735), Dolný budmerický rybník (1584 až 1735), Horný vištucký rybník (1578 až 1735), Dolný vištucký rybník (1580 až 1735) a problematický Schneggen teucht, ktorý sa pravdepodobne nachádzal v Dol’anoch (1585 až 1735). Ako vôbec prvý zanikol Dolný schönauský rybník južne od Budmeríc (pred 1559). Aspoň približné určenie obdobia zániku Horného a Dolného schönauského rybníka komplikuje prítomnost' neznámeho rybníka v priestore medzi Budmericami, Štefanovou a Častou. Ďalšie spresnenie zániku rybníkov na červenokamenskom panstve bude možné uskutočnit' len po podrobnejšom štúdiu písomných prameňov $\mathrm{z}$ archívu panstva či $\mathrm{v}$ rodinnom archíve Fuggerovcov v nemeckom Dillingene. Napriek tomu sa ukázalo, že podrobné štúdium dostupných historických máp a písomných prameňov sprevádzané terénnym výskumom umožnilo identifikáciu krajinných elementov spojených s rybnikárstvom v súčasnej krajine. Vo všetkých prípadoch išlo o relikty po rybničných hrádzach, ktoré sú dnes druhotne využité (ako cesta či nová hrádza), skryté v lesných porastoch či úplne zničené. 
Štúdia vznikla ako súčast’ riešenia projektu „Natura et Cultura. Koevolúcia človeka a prírodného prostredia v 6. až 2. tisícročí pred n.l. v oblasti severne od stredného Dunaja skúmaná na základe archeologických a environmentálnych prameňov“, financovaného v rámci projektu APVV-14-0550.

\section{Pramene a literatúra}

ANDRESKA, J., 1997: Lesk a sláva českého rybářství. Pacov.

BENKOVÁ, E., 2012: Urbár hradného panstva Červený Kameň z 22. októbra 1559. Register príjmov a počtu sedliakov, tak želiarov a prináležitostí prislúchajúcich k hradu Červený Kameň spísaný 22. októbra roku Pána 1559, Štúdie k slovenským dejinám. Historia nova 2, 194-213.

- 2013: Die Kroaten in der Burgherrschaft Červený Kameň im 16. Jahrhundert. In: Kucharská, V.-Kuzmová, S.-Mesiarkin, A., Slovensko a Chorvátsko. Historické vzt’ahy a paralely (do roku 1780). Slovačka i Hrvatska. Povijesne paralele i veze (do godine 1780.), 339-343. Bratislava - Zagreb.

DANGL, V., 2005: Bitky a bojiská v našich dejinách. Od Samovej ríše po vznik stálej armády. Bratislava.

DUBRAVIUS, J., 1953: O rybnících. Praha.

EGYHÁZY-JUROVSKÁ, B., 1980: Zaniknutý románsky kostol s cintorínom v Budmericiach, okr. Bratislava-vidiek, Zborník SNM LXXIV, Historica 20, 39-61.

FRAJER, J.-PAVELKOVÁ CHMELOVÁ, R., 2009: Malé vodní nádrže Hlubokého potoka a jejich historický význam. In: Sborník konference „Říční krajina 6“, 10-16. Olomouc.

HERMANN, O., 1887: A Magyar halászat könyve. Budapest.

HRUBÝ, T., 2015: Osídlenie dolného Považia v stredoveku. Príspevok k dejinám sídelného vývoja západného Slovenska. Trnava - Kraków.

HURT, R., 1960: Dějiny rybnikářství na Moravě a ve Slezsku 1, 2. Ostrava.

CHRASTINA, P., 2005: Využitie krajiny v historickogeografickom kontexte. Trenčianska kotlina a okraje pril'ahlých pohorí, Studia Historica Nitriensia 12, 43-55.

- 2009: Vývoj využívania krajiny Trenčianskej kotliny a jej horskej obruby. Nitra.

- 2010: Vinohradníctvo a rybnikárstvo v Trenčíne a jeho okolí, HG 36, 73-98.

JANKÓ, A., 2013: Vojenské mapovanie 1763-1914. In: Jankó, A.-Porubská, B., Vojenské mapovanie na Slovensku 1769-1883, 7-30. Bratislava.

JANKÓ, A.-PORUBSKÁ, B., 2013: Vojenské mapovanie na Slovensku 1769-1883. Bratislava.

JANŠÁK, Š., 1961: Z minulosti rybnikárstva na potoku Trnávke, Geografický časopis 13, č. 3, $212-222$.

JEDLICSKA, P., 1869: Kalászat a vöröskői levéltárból, Századok 3, 447-465.

- 1882: Kiskárpáti emlékek. Vöröskőtől - Szomolányig. Hely- s müvelődéstörténeti tanulmány. Budapest.

JERŠOVÁ, M., 1957: Z dejín rybárstva a rybnikárstva na Slovensku, HŠ 3, 157-171.

KALUS, P., 1999: Die Fugger in der Slowakei. Augsburg.

KRONIKA ČESKÁ: Přibíka z Radenína, řečeného Pulkava Kronika česká (Bláhová, M.-Pavel, J.-Zachová, J., edd.). Praha 1987.

KUČERA, M., 1974: Slovensko po páde Vel'kej Moravy. Bratislava.

KUCHARSKÁ, V., 2014: Ducissa. Život kňažnej Hedvigy v časoch Jagelovcov. Bratislava.

LOPATKOVÁ, Z., 2010: Buková v novoveku. In: Andraško, I.-Elschek, O.-Elscheková, A.-Jašek, P.-Letavajová, S.-Lopatková, Z.-Nádaská, K.-Nováková, K.-Patinková, J.-Prieško, M., Buková. Vlastivedná monografia obce, 67-79. Žilina.

MALINIAK, P., 2009: Človek a krajina Zvolenskej kotliny v stredoveku. Banská Bystrica.

MARSINA, R., 1959: Urbár hradného panstva Červený Kameň 1543. In: Marsina, R.-Kušík, M., Urbáre feudálnych panstiev na Slovensku I, 69-163. Bratislava.

MARTINKA, J., 1931: Slovenské rybárstvo, Sborník Muzeálnej slovenskej spoločnosti XXV, 65-102.

MÍKA, A., 1955: Slavná minulost českého rybářství. Praha.

MIŠÚTH, V., 2012: Z dejín farnosti Suchá nad Parnou. Suchá nad Parnou.

MJARTAN, J., 1984: L'udové rybárstvo na Slovensku. Bratislava.

MOL, DL: Magyar Országos Levéltár, Diplomatikai Levéltár, Kincstári levéltárból (E), MKA Neo-regestrata acta (Q 311), sign. 23658, https://archives.hungaricana.hu/en/charters/view/297270/ ?pg=0\&bbox=$-1335 \% 2 \mathrm{C}-3734 \% 2 \mathrm{C} 5175 \% 2 \mathrm{C}-103$, cit. 19. 11. 2018.

MOL, DL a: Magyar Országos Levéltár, Diplomatikai Levéltár, Kincstári levéltárból (E), MKA Neo-regestrata acta (Q 311), sign. 13546, https://archives.hungaricana.hu/en/charters/view/ 150110/ $? \mathrm{pg}=0 \&$ bbox $=-1192 \% 2 \mathrm{C}-4403 \% 2 \mathrm{C} 6551 \% 2 \mathrm{C}-83$, cit. 23. 11. 2018. 
MOL, Kataszteri: Magyar Országos Levéltár, S 76 Kataszteri oleáták (1856-1943), Térképtár, No. 575/1-9, No. 575/1-9, Kosolna. Pozsony vármegyei kisközség kataszteri térképének másolata az 1907. évi mérnöki nyilvántartás szerint, cit. 19. 11. 2018.

MOL, Kataszteri a: Magyar Országos Levéltár, S 76 Kataszteri oleáták (1856-1943), Térképtár, No. 1296/1-13, Vistuk. Pozsony vármegyei kisközség kataszteri térképek másolata az 1907. évi mérnöki nyilvántartás szerint, https://maps.hungaricana.hu/en/MOLTerkeptar/13418/view/?pg=7\&bbox= 5695\%2C-4029\%2C9566\% 2C-1870, cit. 23. 11. 2018.

MOL, Katasteri b: Magyar Országos Levéltár, S 76 Kataszteri oleáták (1856-1943), Térképtár, Ottóvölgy. Pozsony vármegyei kisközség kataszteri térképek másolata az 1909. évi mérnöki nyilvántartás szerint, http://maps.hungaricana.hu/hu/view/21306/?pg=12\&bbox=-3019\%2C-8564\%2C12468\%2C732, cit. 23. 11. 2018.

MRVA, I., 2014: Biely Kostol v novoveku. In: Slobodová Nováková, K., Biely Kostol. Vlastivedná monografia obce, 44-65. Bratislava.

NEUMANN, M., 2016: Vývoj rybnikárstva na Slovensku a pokus o rekonštrukciu rybničnej sústavy na červenokamenskom panstve v novoveku, HG 42, 181-207.

PAVELKOVÁ CHMELOVÁ, R. a kol., 2012: Pavelková Chmelová, R.-Frajer, J.-Pavka, P.-Dzuráková, M.Adámek, P., Identification and Analysis of Areas of Historical Ponds (Chrudimka River Basin), Acta Universitatis Olomucensis - Geographica 43, č. 2, 117-132.

PLAČEK, M., 2007: Červený Kameň. In: Plaček, M.-Bóna, M., Encyklopédia slovenských hradov, 94-97. Bratislava.

PRIKRYL, L. V., 1977: Vývoj mapového zobrazovania Slovenska. Bratislava.

RÁBIK, V.-LABANC, P.-TIBENSKÝ, M., 2013: Historická geografia. Trnava.

ROHÁČ, J., 2010: Stredoveká Trnava. In: Šimončič, J. a kol., Dejiny Trnavy I, 83-149. Trnava.

SKLADANÝ, M., 1965: Rybnikárstvo na fuggerovskom panstve Červený Kameň v 16. storočí, HŠ 10 , $22-53$.

ŠIMŮNEK, R., 2015: Krajina třeboňského panství ve středověku a raném novověku. In: Historické krajiny Čech. Třeboňsko - Broumovsko - Praha, 122-244. Praha.

TIBENSKÝ, J., 1998: Poctivá obec budmerická. Starodávna história. Každodenný život slovenskej dediny od najstarších čias do začiatku 18. storočia. Budmerice.

- 2011: Červenokamenské panstvo v stredoveku. Kraków - Trnava.

URBAR 1768: Urbar mestecžka Cžasta. Cseszte, http://archives.hungaricana.hu/hu/urberi/ view/pozsony-cseszte/?document=1\&pg=0\&bbox=-2567\%2C-4105\%2C4967\%2C313, cit. 24. 11. 2018.

VEVERKA, B.-ČECHUROVÁ, M., 2012: Zaniklé rybníky uhříněveské na mapách O. B. Klausera a J. K. Müllera. In: Krajina jako historické jeviště, 143-158. Praha.

WENZEL, G., 1887: Magyarország mezőgazdaságának története. Budapest.

ZACHAROVÁ, A., 2008: Rybolov a rybnikárstvo. Rybárstvo vo svetle archeologických prameňov. Diplomová práca, ulož. na FF UKO, Bratislava.

ŽUDEL, J., 1970: Príspevok k historickej geografii Trnavskej pahorkatiny do polovice 16. storočia, Geografický časopis $22,19-38$.

- 1974: Vplyv ekonomickej činnosti Fuggerovcov na životné prostredie v oblasti červenokamenského panstva v rokoch 1535-1583, Geografický časopis 26, 163-174.

- 1991: Fuggerovci na Červenom Kameni 1535-1583. Bratislava.

\section{Zusammenfassung}

\section{Belege über die Teichwirtschaft in der Herrschaft Červený Kameň}

Mindestens ab dem Mittelalter zählte die Teichwirtschaft zu den beliebten und wirtschaftlich einträglichen Aktivitäten. Nach einer deutlichen Blütezeit der Teichwirtschaft, die sich im 15. und 16. Jahrhundert einstellte, erlebte sie nach und nach in der Form ihren Niedergang, dass die einzelnen Teiche allmählich vernachlässigt oder aufgegeben wurden. Trotz diesem Trend sind in der Landschaft auch heute noch Spuren zu sehen, die Zeugnis über Teichwirtschaftsaktivitäten geben, und zwar nicht nur in den historischen Quellen, sondern auch auf den Darstellungen alter Karten bzw. direkt in der Landschaft. Dies lässt sich vorbildlich am Beispiel der Herrschaft Červený Kameň demonstrieren. Nach dem Jahr 1535 versuchten sie die Fugger als neue Besitzer der Herrschaft wirtschaftlich in die Höhe zu bringen. Dies sollte vor allem 
durch Verbesserung und Ausbau des Teichsystems erfolgen. Im Urbar der Herrschaft Červený Kameň aus dem Jahr 1543 werden bereits 11 Teiche erwähnt. Es ist sehr wahrscheinlich, dass einige von ihnen schon vor Ankunft der Fugger in der Herrschaft existierten. Dies betrifft vor allem den Fančal-Teich, der noch Ende des Mittelalters angelegt worden war. Die Entstehung einiger Teiche kann jedoch erst in die Zeit nach 1535 gelegt werden. Weitaus komplizierter ist es, die Zeit ihres Untergangs zumindest annähernd zu bestimmen. Bis heute haben sich nur zwei Autoren mit dieser Problematik beschäftigt - P. Jedlicska und M. Skladaný. Beide gelangten zu der Auffassung, dass die Frage, wann die Teichsysteme aufgegeben wurden, offen bleibt. Demgegenüber ist es anhand von aus der militärischen Kartierung, aus Katasterkarten oder anderen historischen Quellen (Urbare) gewonnenen Informationen gelungen, die Erkenntnisse im betreffenden Gebiet ein wenig vorzuverlegen. Die Konfrontation beider erwähnten Quellenarten machte es möglich, das Intervall des Untergangs konkreter Teiche enger zu fassen. Die genaueste Bestimmung des Untergangshorizontes konnte im Falle von zwei Teichen im Kataster der Gemeinde Dlhá (Langendorf) gemacht werden (1755 bis 1782-1784). In die Zeit Maria Theresias fällt auch der Untergang des Schönauer Teichs. Irgendwann in der Zeit zwischen 1676 und 1735 muss auch der Teich in Košolná (Kesselstadt) seinem Schicksal überlassen worden sein. Das Untergangsintervall der übrigen Teiche ist ein wenig breiter. Die Untergrenze bildet in den meisten Fällen die letzte bekannte Ausfischung eines Teiches, die Obergrenze dann die Erstellung der Karte des Pressburger Komitats im Jahr 1735. Dies betrifft den Fančal-Teich (1585-1735), den Unteren Teich von Budmerice (1584-1735), den Oberen Vištuk-Teich (1578-1735) sowie den problematischen Teich namens Schneggen teucht, der sich wahrscheinlich in der Nähe des Intravillans der Gemeinde Dol'any (Ottenthal) befand. Der überhaupt erste bekannte Teich, der am frühesten unterging, war der Untere Schönauer Teich (vor 1559). Fraglich bleibt der Beginn und Untergang des Oberen und Unteren Schönauer Teiches, ebenso deren Lokalisierung, die das Vorhandensein eines weiteren jüngeren (?) Teiches im gleichen Raum unmöglich macht. Eine weitere Präzisierung des Unterganges der untersuchten Teiche würde erst ein weiteres Studium in den Fuggerarchiven in Dillingen an der Donau ermöglichen. Trotz gewisser Probleme bei der Definierung einer zumindest annähernden Existenzdauer der einzelnen Teiche war es möglich, im heutigen Gelände Relikte von ihnen zu identifizieren. Dabei handelte es sich vor allem um Teichdämme, die in den meisten Fällen bis heute erhalten geblieben sind. Ihre Lage in der Landschaft konnte anhand einer Georeferenzierung der Kartenunterlagen (vor allem der militärischen Kartierung) mit heutigen Satellitenaufnahmen festgestellt werden.

Die vorliegende Studie entstand als Teil des Projektes „Natura et Cultura. Anhand von archäologischen und environmentalen Quellen untersuchte Koevolution des Menschen und der Umwelt im 6. bis 2. Jahrtausend vor Chr. im Gebiet nördlich der mittleren Donau, und wurde im Rahmen des Förderprojektes APVV-140550 finanziert.

Mgr. et Mgr. Martin Neumann, PhD., Katedra archeológie Filozofickej fakulty Univerzity Komenského, Gondova 2,81499 Bratislava, Slovenská republika,martin.neumann@uniba.sk 
